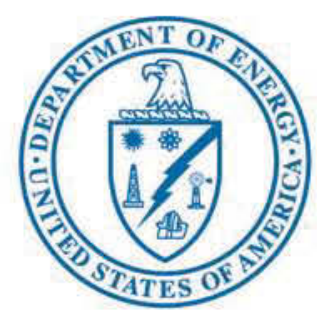

U.S. Department of Energy

Idaho Operations Office

\title{
National Emission Standards for Hazardous Air Pollutants-Calendar Year 2010 INL Report for Radionuclides
}

June 2011

TII daho National Laboratory 

DOE/ID-11441 (2011)

\section{National Emission Standards for Hazardous Air Pollutants-Calendar Year 2010 INL Report for Radionuclides}

June 2011 



\begin{abstract}
This report documents the calendar year 2010 radionuclide air emissions and resulting effective dose equivalent to the maximally exposed individual member of the public from operations at the Department of Energy's Idaho National Laboratory Site. This report was prepared in accordance with the Code of Federal Regulations, Title 40, "Protection of the Environment," Part 61, "National Emission Standards for Hazardous Air Pollutants," Subpart H, "National Emission Standards for Emissions of Radionuclides Other than Radon from Department of Energy Facilities." The effective dose equivalent to the maximally exposed individual member of the public was $5.82 \mathrm{E}-02 \mathrm{mrem}$ per year, 0.58 percent of the 10 mrem standard.
\end{abstract}




\section{CONTENTS}

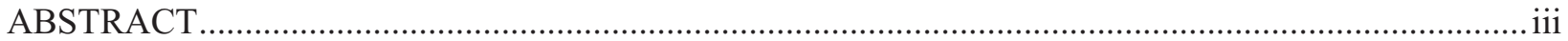

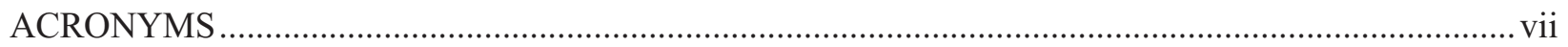

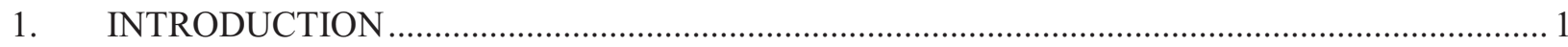

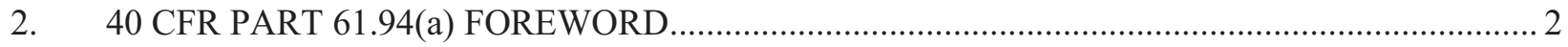

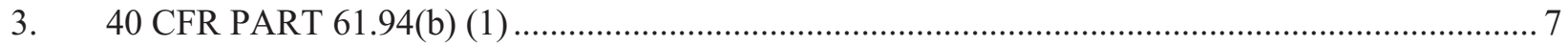

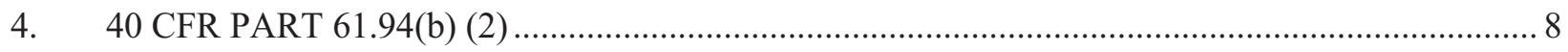

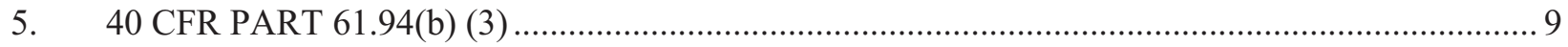

5.1 Advanced Mixed Waste Treatment Project …................................................................... 9

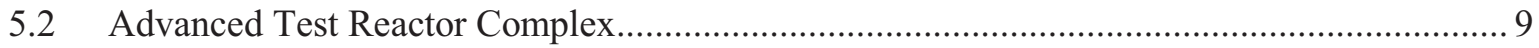

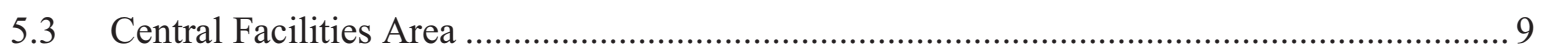

5.4 Idaho Nuclear Technology and Engineering Center ...................................................... 10

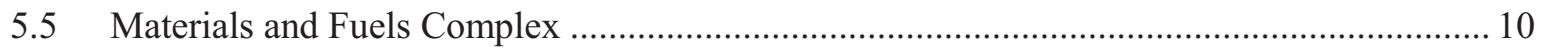

5.6 Radioactive Waste Management Complex .................................................................. 10

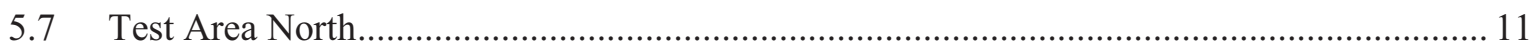

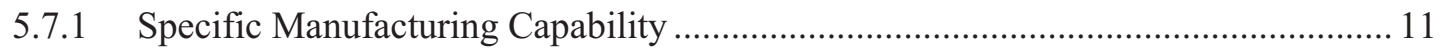

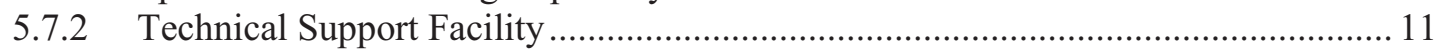

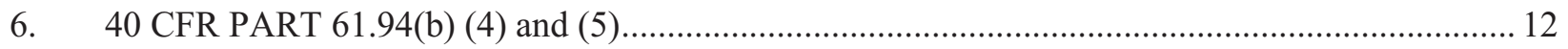

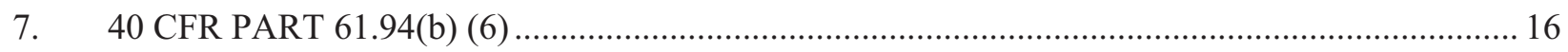

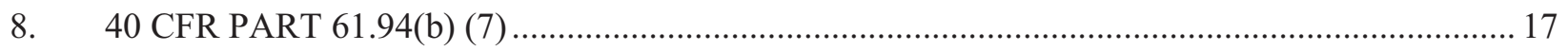

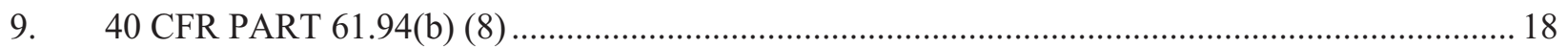

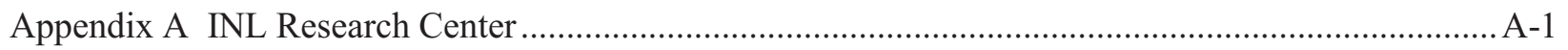

Appendix B Naval Reactors Facility National Emission Standards for Hazardous Air Pollutants_-Radionuclides Annual Report for 2010 ............................................................... B-1

\section{FIGURES}

Figure 1. INL Site, including major facility areas and off-site MEI located at Frenchman's Cabin..........7 


\section{TABLES}

Table 1. Radionuclide emissions, in curies (Ci), from INL Site point sources during CY 2010............... 2

Table 2. Sources used to calculate the EDE to the MEI. 3

Table 3. INL facility dose (mrem) contributions and total INL Site dose (mrem) to the MEI located at Frenchman's Cabin for CY 2010 radionuclide air emissions.

Table 4. Radionuclides in use and potentially emitted to the atmosphere from INL Site facilities in CY 2010 . 8

Table 5. Stacks, vents, or other points of radioactive materials release to the atmosphere at AMWTP..... 12

Table 6. Stacks, vents, or other points of radioactive materials release to the atmosphere at ATR Complex.

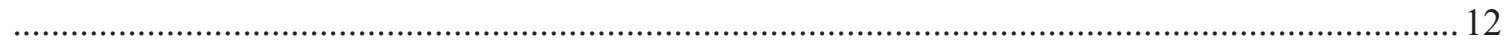

Table 7. Stacks, vents, or other points of radioactive materials release to the atmosphere at CFA........... 13

Table 8. Stacks, vents, or other points of radioactive materials release to the atmosphere at INTEC....... 13

Table 9. Stacks, vents, or other points of radioactive materials released to the atmosphere at MFC........ 14

Table 10. Stacks, vents, or other points of radioactive materials release to the atmosphere at RWMC.... 15

Table 11. Stacks, vents, or other points of radioactive materials release to the atmosphere at SMC........ 15

Table 12. Stacks, vents, or other points of radioactive materials release to the atmosphere at TSF.......... 15

Table 13. Distances from INL facility points of release to the nearest off-Site receptor location and to

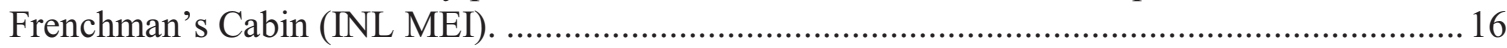

Table 14. Description of data tables in NESHAPS CAP88 database ..................................................... 17

Table 15. INL Site meteorological files and wind measurements heights............................................. 17 


\section{ACRONYMS}

$\begin{array}{ll}\text { AMWTF } & \text { Advanced Mixed Waste Treatment Facility } \\ \text { AMWTP } & \text { Advanced Mixed Waste Treatment Project } \\ \text { ARP } & \text { Accelerated Retrieval Project } \\ \text { ATR } & \text { Advanced Test Reactor } \\ \text { ATR Complex } & \text { Advanced Test Reactor Complex } \\ \text { BEA } & \text { Battelle Energy Alliance, LLC } \\ \text { CAP } & \text { Clean Air Act Assessment Package } \\ \text { CEM } & \text { Continuous Emission Monitoring } \\ \text { CERCLA } & \text { Comprehensive Environmental Response, Compensation, and Liability Act } \\ \text { CFA } & \text { Central Facilities Area } \\ \text { CFR } & \text { Code of Federal Regulations } \\ \text { Ci } & \text { curies } \\ \text { CPP } & \text { Chemical Processing Plant } \\ \text { CWI } & \text { CH2M-WG Idaho, LLC } \\ \text { CY } & \text { calendar year } \\ & \\ \text { D\&D } & \text { decontamination and decommissioning } \\ \text { DOE } & \text { Department of Energy } \\ \text { DOE-ID } & \text { Department of Energy Idaho Operations Office } \\ & \\ \text { EBR-II } & \text { Experimental Breeder Reactor-II } \\ \text { EDE } & \text { effective dose equivalent } \\ \text { EML } & \text { Electron Microscopy Laboratory } \\ \text { EPA } & \text { Environmental Protection Agency } \\ \end{array}$

FAST Fluorinel and Storage Facility

FCF Fuel Conditioning Facility

HEPA high-efficiency particulate air

HFEF Hot Fuel Examination Facility

INL Idaho National Laboratory

INTEC Idaho Nuclear Technology and Engineering Center

IRC INL Research Center

LLMW low-level mixed waste

L\&O Laboratory and Office Building

MEI maximally exposed individual

MFC Materials and Fuels Complex

mrem millirem

MTR Material Test Reactor

MWSF Mixed Waste Storage Facility

NESHAP National Emission Standards for Hazardous Air Pollutants

NOAA National Oceanic and Atmospheric Administration

NRF Naval Reactors Facility 
OCVZ organic contamination in the vadose zone

$\mathrm{OU}$

operable unit

PBF Power Burst Facility

QC quality control

RESL Radiological and Environmental Sciences Laboratory

RCRA Resource Conservation and Recovery Act

RDD radiological dispersion device

$\mathrm{RH} \quad$ remote handled

RH-TRU remote handled transuranic

RWMC Radioactive Waste Management Complex

SDA Subsurface Disposal Area

SMC Specific Manufacturing Capability

TAN Test Area North

TRA Test Reactor Area

TRU transuranic

TSF Technical Support Facility

VCO Voluntary Consent Order

WAG waste area group

WMF Waste Management Facility 


\section{National Emission Standards for Hazardous Air Pollutants-Calendar Year 2010 INL Report for Radionuclides}

\section{INTRODUCTION}

This report documents radionuclide air emissions for calendar year (CY) 2010 and the resulting effective dose equivalent (EDE) to the maximally exposed individual (MEI) member of the public from operations at the U.S. Department of Energy's (DOE's) Idaho National Laboratory (INL) Site.

The title of each section in this report corresponds to reporting requirements found in 40 Code of Federal Regulations (CFR) Part 61.94. A description of the applicable reporting requirements is cited under the titles in italicized text followed by the compliance report for INL Site facilities.

Appendix A contains information specific to INL Research Center (IRC) located in Idaho Falls, Idaho. Radionuclide emissions from the IRC are not included in INL Site EDE calculation. Compliance to the 10-mrem-dose standard is demonstrated by limiting the quantities of radioactive material at the IRC, in accordance with possession limits defined in 40 CFR 61, Appendix E.

Appendix B of this report contains information specific to the Naval Reactors Facility (NRF) located within INL Site boundary. The EDE for NRF radionuclide emissions is included in INL Site EDE to demonstrate overall compliance to the 10-mrem-dose standard set by 40 CFR 61, Subpart H, and "National Emission Standards for Emissions of Radionuclides other than Radon from Department of Energy Facilities."

For CY 2010, modeling was performed using Clean Air Act Assessment Package (CAP)-88PC, Version 3. 


\section{40 CFR PART 61.94(a) FOREWORD}

"Compliance with this standard shall be determined by calculating the highest effective dose equivalent to any member of the public at any offsite point where there is a residence, school, business or office. The owners or operators of each facility shall submit an annual report to both Environmental Protection Agency (EPA) headquarters and the appropriate regional office by June 30, which includes the results of the monitoring as recorded in DOE's Effluent Information System and the dose calculations required by \$61.93(a) for the previous calendar year."

This report documents INL Site radionuclide air emissions and the resulting EDE to the MEI for CY 2010. It was prepared in accordance with the 40 CFR 61, Subpart H. As required, this report is submitted to both the Environmental Protection Agency (EPA) Headquarters and the appropriate regional office (EPA Region 10) no later than June 30, 2011.

Table 1 reports the annual radionuclide emissions for INL Site sources that require continuous monitoring for compliance during CY 2010. Table 2 lists the sources used to calculate the EDE to the MEI.

Table 1. Radionuclide emissions, in curies (Ci), from INL Site point sources during CY 2010.

\begin{tabular}{|c|c|c|c|c|c|c|c|c|}
\hline Radionuclide & $\begin{array}{c}\text { MFC-785- } \\
018^{\mathrm{a}}\end{array}$ & $\begin{array}{c}\text { MFC-764- } \\
001\end{array}$ & $\begin{array}{l}\text { ARPs } \\
1-4^{\mathrm{b}}\end{array}$ & $\begin{array}{c}\text { CPP-708- } \\
001\end{array}$ & $\begin{array}{c}\text { CPP-659- } \\
033 \\
\end{array}$ & $\begin{array}{c}\text { CPP-767- } \\
001\end{array}$ & $\begin{array}{c}\text { WMF-676- } \\
002^{c}\end{array}$ & $\begin{array}{c}\text { WMF-676- } \\
003^{c}\end{array}$ \\
\hline Am-241 & & - & $4.00 \mathrm{E}-03$ & - & - & - & - & - \\
\hline Ar-41 & 9.96 E-01 & - & & - & - & - & - & - \\
\hline Co-60 & - & - & & - & - & - & - & - \\
\hline Cs-137 & - & - & & $7.66 \mathrm{E}-05$ & - & - & - & - \\
\hline $\mathrm{H}-3$ & $3.73 \mathrm{E}-02$ & $4.36 \mathrm{E}+01$ & & & - & - & - & - \\
\hline I-129 & - & - & & & - & - & - & - \\
\hline $\mathrm{Kr}-85$ & $7.96 \mathrm{E}+00$ & $6.02 \mathrm{E}+02$ & & - & - & - & - & - \\
\hline $\mathrm{Pu}-238$ & - & - & & $3.66 \mathrm{E}-07$ & - & $6.07 \mathrm{E}-09$ & - & - \\
\hline $\mathrm{Pu}-239$ & $3.68 \mathrm{E}-07$ & $2.90 \mathrm{E}-07$ & $5.50 \mathrm{E}-04$ & $4.68 \mathrm{E}-08$ & $6.99 \mathrm{E}-10$ & & - & - \\
\hline $\mathrm{Pu}-240$ & - & - & & - & - & - & - & - \\
\hline Sb-125 & - & - & & - & - & - & - & - \\
\hline Sr-90 & $1.66 \mathrm{E}-06$ & $2.08 \mathrm{E}-06$ & & $4.22 \mathrm{E}-05$ & 8.27E-09 & & - & - \\
\hline Particulate & nonitoring $\mathrm{r}$ & esults have bee & $n$ increased & Sept-Dec to ac & ount for probe $\mathrm{r}$ & isalignment. & & \\
\hline $\begin{array}{l}\text { b. Radionuclic } \\
\text { CAP88 mo }\end{array}$ & $\begin{array}{l}\text { issions from } \\
\text { ee discussion }\end{array}$ & $\begin{array}{l}\text { the ARP enclo } \\
\text { of ARP in sect }\end{array}$ & $\begin{array}{l}\text { sures are calc } \\
\text { ion 5.6). }\end{array}$ & ated and prese & ed here to demo & nstrate INL site & wide compliance & e using the \\
\hline c. No measurab & nissions in 2 & 010 & & & & & & \\
\hline
\end{tabular}


Table 2. Sources used to calculate the EDE to the MEI.

\begin{tabular}{|c|c|}
\hline Facility & Source \\
\hline \multirow{6}{*}{$\begin{array}{l}\text { Advanced Mixed } \\
\text { Waste Treatment } \\
\text { Project (AMWTP): }\end{array}$} & Waste Management Facility (WMF)-615-001, Drum Vent Facility \\
\hline & WMF-628-002, Drum Treatment Facility \\
\hline & WMF-634-001, Characterization Facility \\
\hline & WMF-636-001, Transuranic Storage Area-Retrieval Enclosure \\
\hline & $\begin{array}{l}\text { WMF-676-002, Advanced Mixed Waste Treatment Facility (AMWTF) Zone } 3 \\
\text { Stack }\end{array}$ \\
\hline & WMF-676-003, AMWTF Glovebox Stack \\
\hline \multirow[t]{13}{*}{ ATR Complex: } & $\begin{array}{l}\text { Test Reactor Area (TRA)-603, -604, -661, -668 MTR Decontamination \& } \\
\text { Decommissioning (D\&D) }\end{array}$ \\
\hline & TRA-613A Pump Vault Removal \\
\hline & $\begin{array}{l}\text { TRA-670-074, Advanced Test Reactor (ATR) Chemistry Laboratory fume hoods } \\
\text { exhaust }\end{array}$ \\
\hline & TRA-670-086, laboratory \\
\hline & TRA-670-098, laboratory \\
\hline & TRA-670, ATR canal \\
\hline & TRA-678-001, Radiation Measurements Laboratory fume hoods vent \\
\hline & TRA-710-001, Material Test Reactor (MTR) stack \\
\hline & TRA-715-001, Warm Waste Evaporation Pond \\
\hline & TRA-770-001, ATR main stack \\
\hline & TRA-004 D\&D \\
\hline & D\&D TRA-630, 730 \\
\hline & TRA-632 D\&D \\
\hline \multirow{5}{*}{$\begin{array}{l}\text { Central Facilities Area } \\
\text { (CFA): }\end{array}$} & CFA-690-001, -002, -003, -005, -006, -007, -008, -009, -045, -046, -047, \\
\hline & -Vent-195, Radiological and Environmental Sciences Laboratory (RESL) \\
\hline & CFA-625 \\
\hline & Tritium emissions from pumped aquifer water \\
\hline & CFA-54 Soil Remediation \\
\hline \multirow{13}{*}{$\begin{array}{l}\text { Idaho Nuclear } \\
\text { Technology and } \\
\text { Engineering Center } \\
\text { (INTEC): }\end{array}$} & CPP-602-012, laboratory \\
\hline & CPP-602-014, laboratory \\
\hline & CPP-603-001, Irradiated Fuels Storage Facility \\
\hline & CPP-630-012, laboratory fume hoods and other exhausts \\
\hline & $\begin{array}{l}\text { CPP-653-001, EPA Radiological Dispersion Device (RDD) Decontamination } \\
\text { Project }\end{array}$ \\
\hline & CPP-659-033, NWCF Stack \\
\hline & CPP-663-002, Maintenance Building Hot Shop vent \\
\hline & CPP-684-001, Remote Analytical Laboratory \\
\hline & CPP-708-001, Main Stack \\
\hline & CPP-749-001, Spent Fuel Storage Vaults \\
\hline & CPP-767-001, FAST Stack \\
\hline & CPP-1608-001, Manipulator Repair Cell \\
\hline & CPP-1774, TMI-2 Independent Spent Storage Installation \\
\hline
\end{tabular}




\begin{tabular}{|c|c|}
\hline Facility & Source \\
\hline & CPP-1778, Sewage Treatment Plant \\
\hline & CPP-1791, INTEC percolation ponds \\
\hline & CPP-2707, dry cask storage pad \\
\hline & CPP - undisturbed soil (windblown CPP-88) \\
\hline & CPP- 88 disturbed soils \\
\hline & $\begin{array}{l}\text { INL Comprehensive Environmental Response, Compensation, and Liability Act } \\
\text { (CERCLA) Disposal Facility Landfill (ICDF) emissions from solid waste } \\
\text { disposal }\end{array}$ \\
\hline & ICDF pond emissions \\
\hline & OU 3-13 soils removal \\
\hline \multirow{23}{*}{$\begin{array}{l}\text { Materials and Fuels } \\
\text { Complex (MFC): }\end{array}$} & MFC-704-008, Fuel Manufacturing Facility stack \\
\hline & MFC-720-007, Transient Reactor Test Facility reactor cooling air exhaust \\
\hline & MFC-752-004, Laboratory and Office Building (L\&O) main stack \\
\hline & MFC-752-005, L\&O nondestructive assay stack \\
\hline & $\begin{array}{l}\text { MFC-764-001, Main Stack (Experimental Breeder Reactor [EBR]-II/Fuel } \\
\text { Conditioning Facility (FCF) exhaust) }\end{array}$ \\
\hline & MFC-766, -767, D\&D - sodium removal \\
\hline & MFC-768-105, decontamination shower suspect waste tank vent \\
\hline & MFC-768-108, Health Physics Area fume hood \\
\hline & MFC-771, Radioactive Scrap Waste Facility \\
\hline & MFC-774-026, Electron Microscopy Laboratory (EML) exhaust \\
\hline & MFC-774-027, EML exhaust \\
\hline & MFC-774-028, EML exhaust \\
\hline & MFC-774-029, EML exhaust \\
\hline & MFC-777-002, Zero Power Physics Reactor \\
\hline & MFC-785-018, Hot Fuel Examination Facility stack \\
\hline & MFC-787-001, Fuel Assembly and Storage Building \\
\hline & MFC-792A-001, Space, Security and Power Facility \\
\hline & MFC-793-001, Sodium Components Maintenance Shop stack \\
\hline & MFC-793-A, -B, D\&D, Alcohol removal from tanks \\
\hline & MFC-793A-025, 027, 029, 031, 033, 035; Alcohol Storage Tank vents \\
\hline & MFC-794-006, Contaminated Equipment Storage Building exhaust \\
\hline & MFC-798-017, Radioactive Liquid Waste Treatment Facility \\
\hline & MFC-1704, Radio Chemistry Laboratory \\
\hline \multicolumn{2}{|c|}{ Naval Reactors Facility See Appendix B } \\
\hline \multirow{6}{*}{$\begin{array}{l}\text { Radioactive Waste } \\
\text { Management Complex } \\
\text { (RWMC): }\end{array}$} & ICP Analytical Services \\
\hline & WMF-601-001, Health Physics Laboratory Hood \\
\hline & WMF-697-001, Accelerated Retrieval Project (ARP)-1 \\
\hline & WMF-714, Intermediate-level Transuranic Storage Facility \#1 \\
\hline & WMF-720, Intermediate-level Transuranic Storage Facility \#2 \\
\hline & WMF-1612-001, ARP-2 \\
\hline
\end{tabular}




\begin{tabular}{ll}
\hline \multicolumn{1}{c}{ Facility } & \\
& WMF-1614-001, ARP-3 \\
& WMF-1615-001, ARP-4 \\
& H-3 from groundwater \\
& Subsurface Disposal Area (SDA) Organic Contamination in the Vadose Zone \\
& (OCVZ)-Unit D (WAG 7) \\
& OCVZ-Unit E (WAG 7) \\
& OCVZ-Unit F (WAG 7) \\
& SDA Buried Beryllium Blocks \\
& RWMC In Situ Grouting \\
\hline Test Area North (TAN) & 629-013, manufacturing process, Line 2A \\
Specific Manufacturing & 679-022, -023, -024 manufacturing process, north process \\
Capability (SMC): & 679-025, -026, -027 manufacturing process, south process \\
& 681-016, Process Reclamation Facility \\
& 681-018, Process Reclamation Facility \\
& 681-020, Process Reclamation Facility \\
\hline Test Area North (TAN) & OU 1-07B, New Pump and Treat Facility \\
Technical Support & \\
Facility (TSF): & \\
\hline
\end{tabular}

40 CFR 61, Subpart H requires DOE facilities to calculate the resulting dose to the offsite MEI. As in previous years, Frenchman's Cabin was the location of INL Site MEI for CY 2010 (see Figure 1).

Historically, the calculated EDE for INL has been less than 0.1 millirem (mrem) per year. The EDE to the MEI was 5.82E-02 mrem/yr (5.82E-07 sievert/yr), which is $0.58 \%$ of the $10-\mathrm{mrem} / \mathrm{yr}$ federal standard and was calculated using all sources that emitted radionuclides to the environment from INL. Table 3 provides a summary of INL Site MEI dose by facility and source type. 
Table 3. INL facility dose (mrem) contributions and total INL Site dose (mrem) to the MEI located at Frenchman's Cabin for CY 2010 radionuclide air emissions.

\begin{tabular}{|c|c|c|c|c|}
\hline Facility ID & $\begin{array}{c}\text { Point source } \\
\text { dose }(\mathrm{mrem} / \mathrm{yr})\end{array}$ & $\begin{array}{l}\text { Fugitive source } \\
\text { dose (mrem/yr) }\end{array}$ & $\begin{array}{l}\text { Total dose } \\
\text { (mrem/yr) }\end{array}$ & Notes \\
\hline CFA & $5.17 \mathrm{E}-03$ & $1.37 \mathrm{E}-05$ & $5.18 \mathrm{E}-03$ & Central Facilities Area \\
\hline INTEC & $1.36 \mathrm{E}-05$ & $1.18 \mathrm{E}-02$ & $1.18 \mathrm{E}-02$ & $\begin{array}{l}\text { Idaho CERCLA Disposal Facility } \\
\text { and other INTEC soils }\end{array}$ \\
\hline INTEC-MS & $3.58 \mathrm{E}-06$ & & $3.58 \mathrm{E}-06$ & INTEC Main Stack \\
\hline INTEC Total & $1.72 \mathrm{E}-05$ & $1.18 \mathrm{E}-02$ & $1.18 \mathrm{E}-02$ & Total from INTEC sources \\
\hline MFC & $6.95 \mathrm{E}-06$ & 3.04E-04 & $3.11 \mathrm{E}-04$ & Material Fuels Complex \\
\hline MFC-MS & $5.40 \mathrm{E}-05$ & & $5.40 \mathrm{E}-05$ & Material Fuels Complex, Main Stack \\
\hline MFC Total & $6.10 \mathrm{E}-05$ & 3.04E-04 & $3.65 \mathrm{E}-04$ & Total from MFC sources \\
\hline NRF & 4.84E-06 & $2.11 \mathrm{E}-06$ & $6.95 \mathrm{E}-06$ & Naval Reactor Facility \\
\hline ATR Complex & $2.10 \mathrm{E}-04$ & $5.61 \mathrm{E}-03$ & $5.82 \mathrm{E}-03$ & ATR Complex \\
\hline $\begin{array}{l}\text { ATR Complex- } \\
\text { ATR }\end{array}$ & $8.28 \mathrm{E}-03$ & & 8.28E-03 & $\begin{array}{l}\text { Advanced Test Reactor Main Stack } \\
\text { at ATR Complex }\end{array}$ \\
\hline $\begin{array}{l}\text { ATR Complex - } \\
\text { MTR }\end{array}$ & $8.15 \mathrm{E}-05$ & & $8.15 \mathrm{E}-05$ & $\begin{array}{l}\text { Materials Test Reactor at ATR } \\
\text { Complex }\end{array}$ \\
\hline $\begin{array}{l}\text { ATR Complex } \\
\text { Total }\end{array}$ & 8.57E-03 & $5.61 \mathrm{E}-03$ & $1.42 \mathrm{E}-02$ & Total from ATR Complex sources \\
\hline AMWTP & $6.45 \mathrm{E}-03$ & & $6.45 \mathrm{E}-03$ & $\begin{array}{l}\text { Advance Mixed Waste Treatment } \\
\text { Plant (includes WMF-636, WMF- } \\
\text { 634, WMF-628-002, WMF-615) }\end{array}$ \\
\hline RWMC & $1.70 \mathrm{E}-04$ & $2.01 \mathrm{E}-02$ & $2.02 \mathrm{E}-02$ & $\begin{array}{l}\text { Others sources at Radioactive Waste } \\
\text { Management Complex }\end{array}$ \\
\hline RWMC Total & $6.62 \mathrm{E}-03$ & $2.01 \mathrm{E}-02$ & $2.67 \mathrm{E}-02$ & Total from RWMC sources \\
\hline TAN SMC & $2.46 \mathrm{E}-09$ & & $2.46 \mathrm{E}-09$ & $\begin{array}{l}\text { Test Area North -Specific } \\
\text { Manufacturing Capability }\end{array}$ \\
\hline TAN-TSF & $1.44 \mathrm{E}-07$ & & $1.44 \mathrm{E}-07$ & $\begin{array}{l}\text { Test Area North - Technical } \\
\text { Services Facility }\end{array}$ \\
\hline TOTAL & $2.04 \mathrm{E}-02$ & $3.78 \mathrm{E}-02$ & $5.82 \mathrm{E}-02$ & \\
\hline
\end{tabular}




\section{40 CFR PART 61.94(b) (1)}

"Name and location of the facility."

Site Name: Idaho National Laboratory Site.

Site Location: The INL Site encompasses approximately $890 \mathrm{mi}^{2}$ on the upper Snake River Plain in southeastern Idaho (see Figure 1). The nearest INL boundaries to population centers are approximately $22 \mathrm{mi}(35.3 \mathrm{~km})$ west of Idaho Falls, $23 \mathrm{mi}(37 \mathrm{~km})$ northwest of Blackfoot, $44 \mathrm{mi}(70.8 \mathrm{~km})$ northwest of Pocatello, $7 \mathrm{mi}(11.3 \mathrm{~km})$ east of Arco, $1 \mathrm{mi}(1.6 \mathrm{~km})$ north of Atomic City, $3 \mathrm{mi}(5 \mathrm{~km})$ west of Mud Lake, and $4 \mathrm{mi}(6 \mathrm{~km})$ east of Howe.

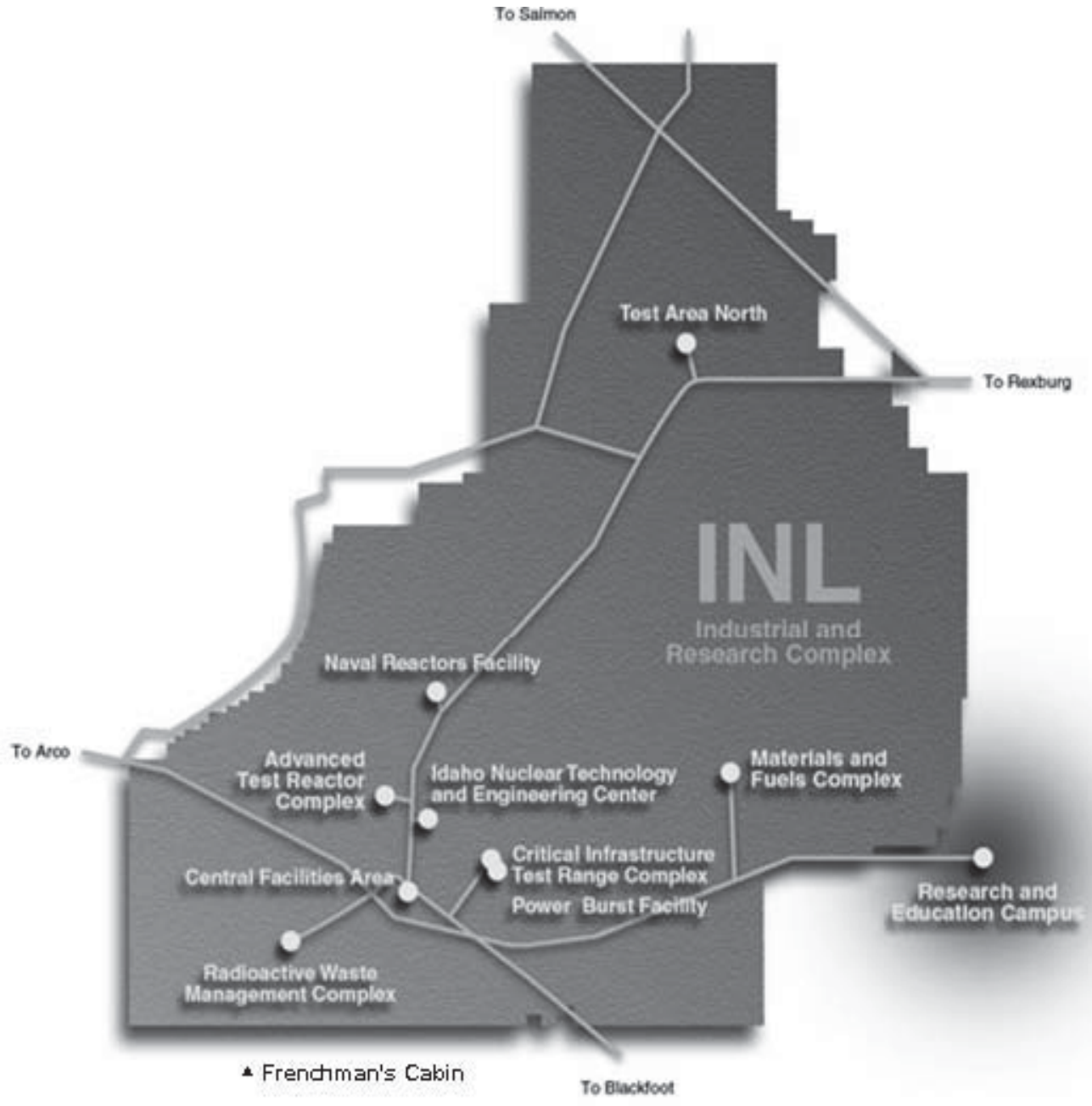

Figure 1. INL Site, including major facility areas and off-site MEI located at Frenchman's Cabin. 


\section{4. $\quad 40$ CFR PART 61.94(b) (2)}

"A list of the radioactive materials used at the facility."

The individual radionuclides found in materials used at INL Site during CY 2010 are listed in Table 4. These materials included, but were not limited to, samples, products, process solids, liquids, and wastes that have potential emissions.

Table 4. Radionuclides in use and potentially emitted to the atmosphere from INL Site facilities in CY 2010.

\begin{tabular}{|c|c|c|c|c|}
\hline Ac-227 & $\mathrm{Cm}-247$ & $\mathrm{Kr}-85 \mathrm{~m}$ & $\mathrm{Pu}-244$ & Ta-182 \\
\hline Ag-108m & Co-57 & Kr-87 & $\mathrm{Pu}-240$ & Ta-183 \\
\hline $\mathrm{Ag}-110 \mathrm{~m}$ & Co-58 & La-140 & $\mathrm{Pu}-241$ & Tc-99 \\
\hline Am-241 & Co-60 & La-142 & $\mathrm{Pu}-242$ & Tc-99m \\
\hline Am-243 & Co-60m & Mn-53 & Ra-224 & Te-123m \\
\hline Ar-39 & Cr-51 & Mn-54 & Ra-226 & Th-228 \\
\hline Ar-41 & Cs-134 & Mn-56 & $\mathrm{Rb}-88$ & Th-230 \\
\hline Ba-133 & Cs-136 & Mo-93 & $\mathrm{Rb}-89$ & Th-232 \\
\hline Ba-137m & Cs-137 & Mo-99 & Re-184 & Tl-204 \\
\hline Ba-139 & Cs-138 & $\mathrm{Na}-24$ & Re-184m & Tl-208 \\
\hline Ba-140 & Eu-152 & $\mathrm{Nb}-93 \mathrm{~m}$ & Re-186 & U-232 \\
\hline Ba-141 & Eu-154 & $\mathrm{Nb}-94$ & Re-186m & U-233 \\
\hline $\mathrm{Be}-7$ & Eu-155 & $\mathrm{Nb}-95$ & Re-187 & U-234 \\
\hline Be-10 & Eu-156 & Ni-59 & Re-188 & U-235 \\
\hline Bi-210 & $\mathrm{Fe}-55$ & Ni-63 & Rh-105 & U-236 \\
\hline $\mathrm{Bi}-210 \mathrm{~m}$ & Fe-59 & $\mathrm{Np}-237$ & Rh-106 & U-237 \\
\hline Bi-212 & $\mathrm{Fe}-60$ & $\mathrm{~Np}-239$ & Ru-103 & U-238 \\
\hline $\mathrm{Br}-83$ & Ge-71 & Os-185 & Ru-106 & $V-49$ \\
\hline C-14 & H-3 & Os-191 & $\mathrm{Sb}-122$ & W-181 \\
\hline $\mathrm{Ca}-45$ & Hf-175 & P-32 & Sb-124 & W-185 \\
\hline Cd-109 & Hf-181 & P-33 & $\mathrm{Sb}-125$ & W-187 \\
\hline Ce-141 & Hf-182 & $\mathrm{Pa}-231$ & Sc-46 & W-188 \\
\hline Ce-144 & $\mathrm{Hg}-203$ & $\mathrm{~Pb}-205$ & $\mathrm{Si}-32$ & Xe-133 \\
\hline Cf-249 & I-128 & $\mathrm{Pb}-210$ & Sm-151 & Xe-135 \\
\hline Cf- 250 & I-129 & $\mathrm{Pb}-212$ & Sm-153 & $\mathrm{Xe}-135 \mathrm{~m}$ \\
\hline Cf-251 & $\mathrm{I}-131$ & Pm-147 & Sn-113 & Xe-138 \\
\hline Cf-252 & $\mathrm{I}-132$ & Po-210 & Sr-85 & Y-88 \\
\hline $\mathrm{Cl}-36$ & I-133 & Po-212 & Sr-89 & $Y-90$ \\
\hline $\mathrm{Cm}-242$ & I-134 & Po-216 & Sr-90 & Y-91m \\
\hline $\mathrm{Cm}-243$ & $\mathrm{I}-135$ & Pr-144 & Sr-91 & Y-92 \\
\hline $\mathrm{Cm}-244$ & Ir-192 & $\mathrm{Pu}-236$ & Sr-92 & $\mathrm{Zn}-65$ \\
\hline $\mathrm{Cm}-245$ & $\mathrm{~K}-40$ & $\mathrm{Pu}-238$ & Та-179 & Zr-95 \\
\hline $\mathrm{Cm}-246$ & $\mathrm{Kr}-85$ & $\mathrm{Pu}-239$ & Ta-180m & Zr-97 \\
\hline $\mathrm{Cm}-248$ & $\mathrm{Kr}-88$ & & & \\
\hline
\end{tabular}




\section{40 CFR PART 61.94(b) (3)}

"A description of the handling and processing that the radioactive materials undergo at the facility."

\subsection{Advanced Mixed Waste Treatment Project}

The Advanced Mixed Waste Treatment Project (AMWTP) is located at the RWMC in the southwestern corner of INL and operated by Bechtel BWXT Idaho, LLC. The AMWTP had six potential sources of radionuclide emission in operation during CY 2010. Radionuclide air emissions from the AMWTP may result from the retrieval, characterization, and treatment of transuranic waste, alphacontaminated low-level mixed waste (alpha LLMW), and LLMW. The mission of the AMWTP is to produce final waste forms that are certified for disposal.

\subsection{Advanced Test Reactor Complex}

The ATR Complex is operated by Battelle Energy Alliance, LLC (BEA) and is located in the south central section of INL. The ATR Complex has facilities for studying the performance of reactor materials and equipment components under high neutron flux conditions. The major facility at ATR Complex is the Advanced Test Reactor (ATR). Other operations at ATR Complex include research and development, site remediation, analytical laboratory services, and facility decommissioning and demolition activities.

Radiological air emissions from ATR Complex are primarily associated with operation of the ATR. These emissions include noble gases, iodines, and other mixed fission and activation products. Other radiological air emissions are associated with sample analysis, site remediation, research and development activities, and decommissioning and demolition activities.

For CY 2010, CH2M-WG Idaho, LLC (CWI) radiological emissions were the result of decontamination and demolition activities at TRA-603 (MTR Reactor Building), TRA-604 (MTR Building Wing A), TRA-661 (MTR Laboratories South Wing), TRA-668 (Reactor Wing North Extension), TRA-613A pump vault, TRA-630 courtyard, TRA-630 pump vault and vault sump, TRA-730 catch tank vault and catch tanks 1 through 4, TRA-004 Hot Waste Management System, and TRA-632 Hot Cells. Radiological emissions from these activities were associated with contaminated equipment and waste removal, demolition of contaminated structures, closure of mixed waste tank systems, and contaminated soils characterization and disposal.

\subsection{Central Facilities Area}

The Central Facilities Area (CFA) is located in the south-central section of INL Site. The CFA provides services that support the following INL Site facilities:

DOE Radiological and Environmental Sciences Laboratory (RESL; CFA-690)

Maintenance shops

Vehicle maintenance facilities

Instrument calibration laboratories

Communications and security systems

Fire protection

Medical services

Warehouses

Laboratory Facilities

Other support services facilities 
Decontamination, decommission, and remediation activities.

With the exception of RESL, operations at CFA are conducted by BEA. The RESL is operated directly by the Department of Energy Idaho Operations Office (DOE-ID).

Minor emissions occur from CFA facilities where work with small quantities of radioactive materials is routinely conducted. This includes low-level radiological performance testing samples preparation and verification at RESL (CFA-690) and radiochemical research and development (CFA-625). Other minor emissions result from research and development laboratory operations and groundwater usage.

In 2010, CWI conducted soil remediation at site CFA-54, a contaminated soil site. Minor emissions are reported from that activity.

\subsection{Idaho Nuclear Technology and Engineering Center}

The Idaho Nuclear Technology and Engineering Center (INTEC) is located in the southern portion of INL. As its primary mission, it began operations in 1953 to recover and reprocess spent nuclear fuel. It was operated for DOE-ID by CWI for this reporting period (CY-10).

Radiological air emissions from INTEC sources are primarily associated with liquid waste operations, including effluents from the Tank Farm Facility, Process Equipment Waste Evaporator, and Liquid Effluent Treatment and Disposal, which are exhausted through the Main Stack. These radioactive emissions include particulates and gaseous radionuclides. Additional radioactive emissions are associated with decommissioning and decontamination activities, decontamination and debris treatment operations, wet-to-dry spent nuclear fuel movements, site remediation, RH-TRU waste management, radiological and hazardous waste storage facilities, and contaminated equipment maintenance.

In 2010, BEA had radioactive emissions from the EPA radiological dispersion device (RDD) Decontamination Project. Minor emissions are reported from this activity.

\subsection{Materials and Fuels Complex}

The Materials and Fuels Complex (MFC) is located in the southeastern corner of INL Site. MFC, a research facility operated by BEA, is involved in advanced nuclear power research and development, spent fuel and waste treatment technologies, national security programs, and projects to support space exploration.

Radiological air emissions are primarily associated with spent fuel treatment at the Fuel Conditioning Facility (FCF) and waste characterization at the Hot Fuel Examination Facility (HFEF). Both of these facilities are equipped with continuous emission monitoring (CEM) systems. On a monthly basis, the effluent streams from FCF, HFEF, and other non-CEM radiological facilities are sampled and analyzed for particulate radionuclides. The FCF and HFEF are also sampled monthly for gaseous radionuclides. Gaseous and particulate radionuclides may also be released from other MFC facilities during laboratory research activities, sample analysis, waste handling and storage, and maintenance operations. Both measured and estimated emissions from MFC sources are consolidated for NESHAP reporting on an annual basis.

In 2010, CWI decontamination and demolition activities involved several MFC facilities, including MFC-766, Sodium Boiler Building, MFC-767, EBR-II Reactor Plant Building, and MFC-793-A, alcohol recovery tanks. Radiological emissions are reported from these activities.

\subsection{Radioactive Waste Management Complex}

The Radioactive Waste Management Complex (RWMC), located in the southwestern corner of INL, is a controlled-access area with a primary mission to safely dispose of INL-generated low-level radioactive waste and to temporarily store contact-handled and remote-handled transuranic waste that will be shipped to other designated facilities for disposal. In addition, various activities are being conducted in the Subsurface Disposal Area at the RWMC to complete environmental cleanup of the area under CERCLA. These include waste retrieval activities (Accelerated Retrieval Projects - ARP), in situ grouting 
of buried waste within the Subsurface Disposal Area (SDA), and operation of several units that extract volatile organic compounds from the subsurface.

Unabated emissions from the ARP exceed $0.1 \mathrm{mrem} / \mathrm{yr}$. By agreement with EPA, ARP uses ambient air monitoring as an alternative to air dispersion calculations to verify compliance with the standard. Therefore, record sampling is not performed, although CAMs are used for real-time monitoring for detection of off-normal emissions. Radionuclide emissions from the ARP enclosures are calculated for use with emissions measurements from other INL sources to demonstrate INL site-wide compliance using the CAP88 model. Based on comparison of the fractions of the NESHAP standard as evaluated using ambient air measurements and calculated emissions, the calculated emissions presented in Table 1 are conservative by approximately a factor of 10 .

To fulfill these missions, the RWMC maintains facilities and processes in separate areas for administrative and operations support, and waste storage and disposal. Administrative and Operations Area buildings are used for security and access control, personnel offices, lunchrooms, change and shower rooms, equipment and materials storage, craft and maintenance shops, and radiological control. This section covers the Operations at the RWMC conducted by CWI, under the administration of DOE Idaho and does not include those operations performed by other contractors under the administration of DOE.

\subsection{Test Area North}

Test Area North (TAN) is the northernmost developed area within INL. It was originally established to support the Aircraft Nuclear Propulsion Program, which operated from 1951 to 1961. Since 1961, TAN buildings have been adapted for use by various other programs, including current BEA operations at the Specific Manufacturing Capability (SMC) facility.

\subsubsection{Specific Manufacturing Capability}

The Specific Manufacturing Capability (SMC) Project, managed by BEA, is a manufacturing operation that produces an armor package for the U.S. Department of the Army. The SMC Project was assigned to INL Site in mid-1983. Operations at SMC include material development, fabrication, and assembly work to produce armor packages. The operation uses standard metal-working equipment in fabrication and assembly. Other activities include developing tools and fixtures and preparing and testing metallurgical specimens. Radiological air emissions from SMC are associated with processing of depleted uranium. Potential emissions are uranium isotopes and associated radioactive progeny.

\subsubsection{Technical Support Facility}

Radioactive air emissions from the Technical Support Facility (TSF) during CY 2010 were primarily associated the New Pump and Treat Facility (NPTF). Its purpose is to reduce concentrations of TCE and other volatile organic compounds (VOCs) in the medial zone portion of the Operable Unit (OU) 1-07B contamination groundwater plume at TAN to below drinking water standards. Low levels of Sr-90 and H-3 are also present in the treated water and are released to the atmosphere by the treatment process. 


\section{40 CFR PART 61.94(b) (4) and (5)}

"A list of the stacks or vents or other points where radioactive materials are released to the atmosphere. A description of the effluent controls that are used on each stack, vent, or other release point and an estimate of the efficiency of each control device."

Tables 5 through 12 list the facility stacks, vents, or other points where radioactive materials were released to the atmosphere during CY 2010.

Table 5. Stacks, vents, or other points of radioactive materials release to the atmosphere at AMWTP.

\begin{tabular}{|c|c|c|c|c|}
\hline Bldg & Vent & Source Description & Effluent Control Description & Efficiency \\
\hline 615 & 001 & Drum Vent Facility & One HEPA filters & $99.97 \%$ each \\
\hline 628 & 002 & Drum Treatment Facility & Two HEPA filters & $99.97 \%$ each \\
\hline \multirow[t]{3}{*}{634} & 001 & Characterization Facility & & \\
\hline & & Drum Vent Facility & Two HEPA filters & $99.97 \%$ each \\
\hline & & Drum Coring & Three HEPA filters & $99.97 \%$ each \\
\hline 636 & 001 & $\begin{array}{l}\text { Transuranic Storage Area- } \\
\text { Retrieval Enclosure }\end{array}$ & NA & NA \\
\hline 676 & 002 & $\begin{array}{l}\text { Advanced Mixed Waste } \\
\text { Treatment Facility } \\
\text { (AMWTF) Zone } 3 \text { Stack }\end{array}$ & Three HEPA Filters & $99.97 \%$ each \\
\hline 676 & 003 & AMWTF Glovebox Stack & Three HEPA Filters & $99.97 \%$ \\
\hline
\end{tabular}

Table 6. Stacks, vents, or other points of radioactive materials release to the atmosphere at ATR Complex.

\begin{tabular}{|c|c|c|c|c|}
\hline Bldg & Vent & Source Description & Effluent Control Description & Efficiency \\
\hline 670 & 074 & $\begin{array}{l}\text { Laboratory } 124 \text { fume hoods } \\
\text { exhaust }\end{array}$ & HEPA filter & $99.97 \%$ \\
\hline 670 & 086 & $\begin{array}{l}\text { Laboratory } 131 \text { fume hoods } \\
\text { exhaust }\end{array}$ & HEPA filter & $99.97 \%$ \\
\hline 670 & 098 & $\begin{array}{l}\text { Laboratory } 103 \text { fume hoods } \\
\text { exhaust (two hoods) }\end{array}$ & HEPA filter & $99.97 \%$ \\
\hline 670 & NA & ATR Canal & NA & NA \\
\hline 678 & 001 & $\begin{array}{l}\text { Radiation Measurements } \\
\text { Laboratory fume hoods vent }\end{array}$ & HEPA Filter & $99.97 \%$ \\
\hline 710 & 001 & MTR Stack & Partial HEPA filtered $^{\mathrm{a}}$ & $99.97 \%$ \\
\hline 715 & 001 & Evaporation Pond & NA & NA \\
\hline 770 & 001 & ATR Main Stack & NA & NA \\
\hline
\end{tabular}

a. HEPA filters are on the effluent from the Safety and Tritium Applied Research Facility (TRA666) 
Table 7. Stacks, vents, or other points of radioactive materials release to the atmosphere at CFA.

\begin{tabular}{|c|c|c|c|c|}
\hline Bldg & Vent & Source Description & Effluent Control Description & Efficiency \\
\hline 625 & 010 & Laboratory fume hoods & HEPA Filter bank ${ }^{\mathrm{a}}$ & $99.97 \%$ \\
\hline 690 & 001 & RESL & NA & NA \\
\hline 690 & 002 & RESL & NA & NA \\
\hline 690 & 003 & RESL & NA & NA \\
\hline 690 & 005 & RESL & NA & NA \\
\hline 690 & 006 & RESL & NA & NA \\
\hline 690 & 007 & RESL & NA & NA \\
\hline 690 & 008 & RESL & NA & NA \\
\hline 690 & 009 & RESL & NA & NA \\
\hline 690 & 045 & RESL & NA & NA \\
\hline 690 & 046 & RESL & NA & NA \\
\hline 690 & 047 & RESL & NA & NA \\
\hline 690 & 195 & RESL & NA & NA \\
\hline
\end{tabular}

Table 8. Stacks, vents, or other points of radioactive materials release to the atmosphere at INTEC.

\begin{tabular}{|c|c|c|c|c|}
\hline Bldg & Vent & Source Description & Effluent Control Description & Efficiency \\
\hline 602 & 012 & $\begin{array}{l}\text { Main exhaust for laboratory fume } \\
\text { hoods, gloveboxes, and denitrator }\end{array}$ & $\begin{array}{l}\text { HEPA filter or two HEPA } \\
\text { filters in series }\end{array}$ & $99.97 \%$ each \\
\hline 602 & 014 & $\begin{array}{l}\text { Laboratory fume hoods and other } \\
\text { exhausts }\end{array}$ & HEPA filter & $99.97 \%$ \\
\hline 603 & 001 & Irradiated Fuel Storage Facility & Two HEPA filters in series & $99.97 \%$ each \\
\hline 630 & 012 & $\begin{array}{l}\text { Laboratory fume hoods and other } \\
\text { exhausts }\end{array}$ & Two HEPA filters in series & $99.97 \%$ each \\
\hline 653 & 001 & $\begin{array}{l}\text { EPA RDD Decontamination } \\
\text { Project }\end{array}$ & HEPA filter & $99.97 \%$ \\
\hline 659 & 033 & NWCF Stack & HEPA Filter & $99.97 \%$ \\
\hline 663 & 002 & $\begin{array}{l}\text { Maintenance building hot shop } \\
\text { vent }\end{array}$ & HEPA filter & $99.97 \%$ \\
\hline 684 & 001 & Remote Analytical Laboratory & Two HEPA filters in series & $99.97 \%$ each \\
\hline 708 & 001 & INTEC Main Stack & $\begin{array}{l}\text { HEPA filter or up to three } \\
\text { HEPA filters in series }\end{array}$ & $99.97 \%$ each \\
\hline 767 & 001 & $\begin{array}{l}\text { Flourinel and Storage Facility } \\
\text { (FAST) Stack }\end{array}$ & $\begin{array}{l}\text { HEPA filter or two HEPA } \\
\text { filters in series }\end{array}$ & $99.97 \%$ each \\
\hline 1608 & 001 & Manipulator Repair Cell & Two HEPA filters in series & $99.97 \%$ each \\
\hline 1774 & - & $\begin{array}{l}\text { TMI-2 Independent Spent Fuel } \\
\text { Storage Installation }\end{array}$ & HEPA filter & $99 \%$ \\
\hline
\end{tabular}


Table 9. Stacks, vents, or other points of radioactive materials released to the atmosphere at MFC.

\begin{tabular}{|c|c|c|c|c|}
\hline Bldg & Vent & Source Description & Effluent Control Description & Efficiency \\
\hline 704 & 008 & $\begin{array}{l}\text { Fuel Manufacturing Facility } \\
\text { stack }\end{array}$ & $\begin{array}{l}\text { Two HEPA filter banks }{ }^{\mathrm{a}} \text { in } \\
\text { series }\end{array}$ & $99.97 \%$ each \\
\hline 720 & 007 & $\begin{array}{l}\text { Transient Reactor Test Facility } \\
\text { reactor cooling air exhaust }\end{array}$ & Two HEPA filter banks in series & $99.97 \%$ each \\
\hline 752 & 004 & $\begin{array}{l}\text { Laboratory and Office (L\&O) } \\
\text { Building main stack }\end{array}$ & Two HEPA filter banks in series & $99.97 \%$ each \\
\hline 752 & 005 & $\begin{array}{l}\text { L\&O Building nondestructive } \\
\text { assay building stack }\end{array}$ & $\begin{array}{l}\text { One to four HEPA filters in } \\
\text { series }\end{array}$ & $99.97 \%$ each \\
\hline 764 & 001 & Main Stack & $\begin{array}{l}\text { EBR-II-HEPA filter bank } \\
\text { FCF-Two HEPA filter banks }\end{array}$ & $99.97 \%$ each \\
\hline 768 & 105 & $\begin{array}{l}\text { Decontamination shower } \\
\text { suspect waste tank vent }\end{array}$ & HEPA filter bank & $99.97 \%$ \\
\hline 768 & 108 & $\begin{array}{l}\text { Health Physics area fume } \\
\text { hoods }\end{array}$ & HEPA filter bank & $99.97 \%$ \\
\hline 771 & NA & $\begin{array}{l}\text { Radioactive Scrap Waste } \\
\text { Facility }\end{array}$ & NA & NA \\
\hline 774 & 026 & EML exhaust & Two HEPA filter banks in series & $99.97 \%$ each \\
\hline & 027 & EML exhaust & Two HEPA filter banks in series & $99.97 \%$ each \\
\hline & 028 & EML exhaust & Two HEPA filter banks in series & $99.97 \%$ each \\
\hline & 029 & EML exhaust & Two HEPA filter banks in series & $99.97 \%$ each \\
\hline 777 & 002 & $\begin{array}{l}\text { Zero Power Physics Reactor } \\
\text { exhaust }\end{array}$ & Two HEPA filter banks in series & $99.97 \%$ each \\
\hline 785 & 018 & $\begin{array}{l}\text { Hot Fuel Examination Facility } \\
\text { stack }\end{array}$ & Two HEPA filter banks in series & $99.97 \%$ each \\
\hline 787 & 001 & $\begin{array}{l}\text { Fuel Assembly and Storage } \\
\text { Building }\end{array}$ & HEPA filter bank & $99.97 \%$ \\
\hline $792 \mathrm{~A}$ & 001 & $\begin{array}{l}\text { Space, Security and Power } \\
\text { Facility }\end{array}$ & Two HEPA filter banks in series & $99.97 \%$ \\
\hline 793 & 001 & $\begin{array}{l}\text { Sodium Components } \\
\text { Maintenance Shop stack }\end{array}$ & HEPA filter bank & $99.97 \%$ \\
\hline 793A & $\begin{array}{l}025,027 \\
029,031, \\
033,035\end{array}$ & Alcohol storage tank vents & NA & NA \\
\hline 794 & 006 & $\begin{array}{l}\text { Contaminated Equipment } \\
\text { Storage Building exhaust }\end{array}$ & HEPA filter bank & $99.97 \%$ \\
\hline 798 & 017 & $\begin{array}{l}\text { Radioactive Liquid Waste } \\
\text { Treatment Facility }\end{array}$ & HEPA filter bank & $99.97 \%$ \\
\hline 1704 & NA & Radiochemistry Laboratory & HEPA filter bank & $99.97 \%$ \\
\hline \multicolumn{5}{|c|}{ a. Bank includes multiple HEPA filters. } \\
\hline
\end{tabular}


Table 10. Stacks, vents, or other points of radioactive materials release to the atmosphere at RWMC.

\begin{tabular}{cclll}
\hline Bldg & Vent & \multicolumn{1}{c}{ Source Description } & Effluent Control Description & Efficiency \\
\hline 601 & 1 & Health Physics Laboratory Hood & HEPA filter & $99.97 \%$ \\
697 & 1 & ARP-1 & HEPA filter & $99.97 \%$ \\
1612 & 1 & ARP-2 & HEPA filter & $99.97 \%$ \\
1614 & 1 & ARP-3 & HEPA filter & $99.97 \%$ \\
1615 & 1 & ARP-4 & HEPA filter & $99.97 \%$ \\
SDA & 1 & Organic Contaminated Vadose & NA & NA \\
& & Zone (OCVZ)-Unit D (WAG 7) & & NA \\
SDA & 1 & OCVZ-Unit E (WAG-7) & NA & NA \\
SDA & 1 & OCVZ-Unit F (WAG-7) & NA & \\
\hline
\end{tabular}

Table 11. Stacks, vents, or other points of radioactive materials release to the atmosphere at SMC.

\begin{tabular}{|c|c|c|c|c|}
\hline Bldg & Vent & Source Description & Effluent Control Description & Efficiency \\
\hline 629 & 013 & Line 2 , manufacturing process & Two HEPA filter banks & $99.97 \%$ \\
\hline 679 & 022 & $\begin{array}{l}\text { North process (RAD Stack \#11) } \\
\text { manufacturing process (EF-206) } \\
\text { and includes releases from the } \\
\text { quality control (QC) laboratory }\end{array}$ & One HEPA filter bank & $99.97 \%$ \\
\hline 679 & 023 & $\begin{array}{l}\text { North process (RAD Stack \#10) } \\
\text { manufacturing process (EF-205) } \\
\text { and includes releases from the QC } \\
\text { laboratory }\end{array}$ & One HEPA filter bank & $99.97 \%$ \\
\hline 679 & 024 & $\begin{array}{l}\text { North process (RAD Stack \#9) } \\
\text { manufacturing process (EF-204) } \\
\text { and includes releases from the QC } \\
\text { laboratory }\end{array}$ & One HEPA filter bank & $99.97 \%$ \\
\hline 679 & 025 & $\begin{array}{l}\text { South process (RAD Stack \#8) } \\
\text { manufacturing process (EF-203) }\end{array}$ & One HEPA filter bank & $99.97 \%$ \\
\hline 679 & 026 & $\begin{array}{l}\text { South process (RAD Stack \#7) } \\
\text { manufacturing process (EF-202) }\end{array}$ & One HEPA filter bank & $99.97 \%$ \\
\hline 679 & 027 & $\begin{array}{l}\text { South process (RAD Stack \#6) } \\
\text { manufacturing process (EF-201) }\end{array}$ & One HEPA filter bank & $99.97 \%$ \\
\hline 681 & 016 & Process Reclamation Facility & NA & NA \\
\hline 681 & 018 & Process Reclamation Facility & One HEPA filter bank & $99.97 \%$ \\
\hline 681 & 020 & Process Reclamation Facility & One HEPA filter bank & $99.97 \%$ \\
\hline
\end{tabular}

Table 12. Stacks, vents, or other points of radioactive materials release to the atmosphere at TSF.

\begin{tabular}{ccccc}
\hline Bldg. & Vent & Source Description & Effluent Control Description & Efficiency \\
\hline NA & OU-107B Treatment Process & NA & NA
\end{tabular}




\section{40 CFR PART 61.94(b) (6)}

"List distances from the points of release to the nearest residence, school, business or office and the nearest farms producing vegetables, milk, and meat."

Table 13 shows distances from the points of release to the nearest residence, school, business or office, and the nearest farms producing vegetables, milk, and meat.

Table 13. Distances from INL facility points of release to the nearest off-Site receptor location and to Frenchman's Cabin (INL MEI).

\begin{tabular}{lcc}
\hline \multicolumn{1}{c}{ Facility } & $\begin{array}{c}\text { Distance and Direction to Nearest } \\
\text { Residence, }\end{array}$ & $\begin{array}{c}\text { Distance and Direction to } \\
\text { Frenchman's Cabin }\end{array}$ \\
\hline MFC & $8,678 \mathrm{~m}^{\mathrm{a}} \mathrm{SSE}$ & $37,219 \mathrm{~m} \mathrm{WSW}$ \\
CFA & $12,453 \mathrm{~m} \mathrm{SE}$ & $14,359 \mathrm{~m} \mathrm{SW}$ \\
INTEC & $15,333 \mathrm{~m} \mathrm{SSE}$ & $18,718 \mathrm{~m} \mathrm{SSW}$ \\
NRF & $13,714 \mathrm{~m} \mathrm{NNW}$ & $26,675 \mathrm{~m} \mathrm{SSW}$ \\
RWMC/AMWTP & $7,976 \mathrm{~m} \mathrm{SSW}$ & $7,976 \mathrm{~m} \mathrm{SSW}$ \\
TAN & $10,344 \mathrm{~m} \mathrm{E}$ & $54,611 \mathrm{~m} \mathrm{SSW}$ \\
SMC & $12,298 \mathrm{~m} \mathrm{E}$ & $54,405 \mathrm{~m} \mathrm{SSW}$ \\
ATR Complex & $17,421 \mathrm{~m} \mathrm{NW}$ & $19,172 \mathrm{~m} \mathrm{SSW}$ \\
& & \\
a.m $m$ meters. & & \\
\hline
\end{tabular}




\section{8. $\quad 40$ CFR PART 61.94(b) (7)}

"The values used for all other user-supplied input parameters for the computer models (e.g. meteorological data) and the source of these data."

Tables 14 and 15 show the CAP-88 modeling input parameters for CY 2010.

Table 14. Description of data tables in NESHAPS CAP88 database

\begin{tabular}{llll}
\hline \multicolumn{1}{c}{ Table Name } & \multicolumn{1}{c}{ Field Name } & Type & \multicolumn{1}{c}{ Description } \\
\hline UnitDoses & FacilityID & Text & Facility Identification (see Table 1) \\
& Nuclide & Text & Nuclide name \\
& Direction & Text & Direction to MEI \\
& Distance & Double & Distance to MEI \\
& UDose & & Unit dose (mrem/Ci) \\
Releases & SourceID & Text & Source identification \\
& FacilityID & Text & Facility Identification (see Table 1) \\
& Fugitive & Text & Fugitive or Non-Fugitive release flag \\
& Radionuclide & Text & Nuclide name \\
& Q & Double & Release rate (Ci/yr) \\
MkMEIsBySecName & FacilityID & Text & Facility Identification (see Table 1) \\
& SectorName & Text & Text name of the 16, 22.5-degree \\
& & & sectors \\
& Distance & Text & Distance from the facility to the \\
& & & receptor \\
& ReceptorNum & \\
& Long & Receptor number index \\
\hline
\end{tabular}

a. The receptor number is the identification assigned to the 62 receptors surrounding INL. The distance and direction to each receptor varies by facility.

Table 15. INL Site meteorological files and wind measurements heights.

\begin{tabular}{lllc}
\multicolumn{1}{c}{ Facility } & \multicolumn{1}{c}{ Facility ID } & \multicolumn{1}{c}{ Wind File } & $\begin{array}{c}\text { Measurement } \\
\text { Height (m) }\end{array}$ \\
\hline $\begin{array}{l}\text { Central Facilities Area } \\
\text { Idaho Nuclear Technology and }\end{array}$ & CFA & 690L10.WND & 10 \\
$\begin{array}{l}\text { Engineering Center, Idaho CERLA } \\
\text { Disposal Facility }\end{array}$ & & GRIL10.WND & 10 \\
$\begin{array}{l}\text { Idaho Nuclear Technology and } \\
\text { Engineering Center - Main Stack }\end{array}$ & INTEC-MS & GRIU10.WND & 30 \\
$\begin{array}{l}\text { Materials Fuels Complex } \\
\text { Materials Fuels Complex Main Stack }\end{array}$ & MFC & EBRL10.WND & 10 \\
$\begin{array}{l}\text { Naval Reactor Facility } \\
\text { Advanced Test Reactor Complex }\end{array}$ & NRF & ERRU10.WND & 30 \\
$\begin{array}{l}\text { Advanced Test Reactor Complex- } \\
\text { Advanced Test Reactor }\end{array}$ & ATR Complex - ATR & GRIU10.WND & 30 \\
$\begin{array}{l}\text { Advanced Test Reactor Complex- } \\
\text { Materials Test Reactor }\end{array}$ & ATR Complex -MTR & GRIU10.WND & 30 \\
$\begin{array}{l}\text { Radioactive Waste Management } \\
\text { Complex }\end{array}$ & RWMC & RWFL10.WND & 10 \\
$\begin{array}{l}\text { Specific Manufacturing Capability } \\
\text { Test Area North }\end{array}$ & SMC & RWL10.WND & 10 \\
\hline
\end{tabular}




\section{40 CFR PART 61.94(b) (8)}

"A brief description of all construction and modifications which were completed in the calendar year for which the report is prepared, but for which the requirement to apply for approval to construct or modify was waived under $\$ 61.96$ and associated documentation developed by DOE to support the waiver. $E P A$ reserves the right to require that DOE send to EPA all the information that normally would be required in an application to construct or modify, following receipt of the description and supporting documentation"

The new Radiochemistry Laboratory MFC-1704 began operation during the third quarter of CY-2010. The unabated dose was estimated at $3.58 \mathrm{E}-02 \mathrm{mrem} / \mathrm{yr}$.

Potential emissions from new equipment installed in Contaminated Equipment Storage Building MFC-794 were evaluated. Equipment includes general machining tools, four high cold rolling mills and hydraulic shears. The potential unabated dose from this equipment is $4.30 \mathrm{E}-06 \mathrm{mrem} / \mathrm{yr}$.

Potential emissions from new equipment installed in MFC-787 were evaluated. Equipment includes Scanning Electron Microscopes, Electron Probe Micro-Analyzer, Positron Annihilation Spectrometers, Tribometer Differential Scanning Calorimeter, Dilatometer Laser Flash Analyzer and Electrical Discharge Machine. The potential unabated dose from this equipment is $1.78 \mathrm{E}-02 \mathrm{mrem} / \mathrm{yr}$.

Potential emissions from a new program at CPP-1634 were evaluated. The new program is designed to optimize processing techniques for the fabrication of quality densified ceramics using powder processing, pressing and sintering. The process will utilize only depleted uranium. The potential unabated dose from this processing is $4.77 \mathrm{E}-02 \mathrm{mrem} / \mathrm{yr}$.

Potential emissions from a new program at CPP-653 were evaluated. The new program is designed to test various decontamination technologies for the EPA to be used to clean-up after an urban RDD ("dirty bomb") event. The processes will utilize radionuclides such as Cs-137, Co-60 and Sr-90 in less than 1 $\mathrm{mCi}$ amounts. The potential unabated dose from this process is $5.51 \mathrm{E}-03 \mathrm{mrem} / \mathrm{yr}$.

SMC installed and began operation of an evaporator for treatment of low-level radioactive wastewater in CY -10. The evaporator is located in TAN-681. The potential unabated dose was estimated at 1.80E-05 $\mathrm{mrem} / \mathrm{yr}$.

Closure under the Hazardous Waste Management Act and Resource Conservation and Recovery Act, and demolition activities under the CERCLA were performed at the Materials and Fuels Complex (MFC) on buildings MFC-766, MFC-767, and MFC-795. Dose was calculated to the hypothetical maximally exposed individual for MFC emissions; the modeled dose is 8.3E-04 mrem/yr (EDF-9547).

The TRA-630 Catch Tank System Courtyard Components were closed under Resource Conservation and Recovery Act (RCRA) of as part of the Voluntary Consent Order Action Plan VCO-5.8.d. Air emissions from the RCRA closure of the TRA-630 Catch Tank System Courtyard Components. Radiological emissions were estimated to result in a dose to the hypothetical maximally exposed individual member of the public of 1.2E-03 mrem/yr (EDF-8971). 
Appendix A

INL Research Center 
A-2 


\section{Appendix A \\ INL Research Center}

Compliance with the 10-mrem dose standard is demonstrated by use of 40 CFR 61, Appendix E. A comparison of the final inventory for CY 2010 plus all receipts received during the calendar year with the Appendix E limits appears in Table A-1. This table shows the quantity of radioactive material possessed during the calendar year is less than the Appendix E limits.

Table A- 1. 40 CFR 61 Appendix E compliance table.

\begin{tabular}{|c|c|c|c|c|}
\hline Radionuclide & $\begin{array}{c}\text { Physical State of } \\
\text { Inventory }\end{array}$ & $\begin{array}{l}\text { IRC Inventory }^{1} \\
(\mathrm{Ci})\end{array}$ & $\begin{array}{c}\text { Appendix E } \\
\text { Possession Limit } \\
\text { (Ci) }\end{array}$ & $\begin{array}{l}\text { NESHAPS } \\
\text { Ratio }^{2} \\
\end{array}$ \\
\hline Am-241 & Liquid/powder & $1.76 \mathrm{E}-12$ & $2.30 \mathrm{E}-03$ & $7.65 \mathrm{E}-10$ \\
\hline $\mathrm{Cm}-244$ & Liquid/powder & $4.86 \mathrm{E}-14$ & 4.20E-03 & $1.16 \mathrm{E}-11$ \\
\hline Cs-134 & Liquid/powder & $6.26 \mathrm{E}-09$ & $5.20 \mathrm{E}-02$ & $1.20 \mathrm{E}-07$ \\
\hline Cs-137 & Liquid/powder & 7.14E-08 & $2.30 \mathrm{E}-02$ & $3.10 \mathrm{E}-06$ \\
\hline $\mathrm{I}-125$ & Liquid/powder & $1.00 \mathrm{E}-03$ & $6.20 \mathrm{E}+00$ & $1.61 \mathrm{E}-04$ \\
\hline $\mathrm{I}-129$ & Liquid/powder & $2.30 \mathrm{E}-14$ & $2.60 \mathrm{E}-01$ & $8.85 \mathrm{E}-14$ \\
\hline $\mathrm{K}-40$ & Liquid/powder & $1.02 \mathrm{E}-07$ & $6.80 \mathrm{E}-02$ & $1.50 \mathrm{E}-06$ \\
\hline $\mathrm{Kr}-85$ & Gas & $1.03 \mathrm{E}-02$ & $8.40 \mathrm{E}+02$ & $1.23 \mathrm{E}-05$ \\
\hline $\mathrm{Ni}-63$ & Liquid/powder & $9.80 \mathrm{E}-09$ & $1.40 \mathrm{E}+02$ & $7.00 \mathrm{E}-11$ \\
\hline $\mathrm{Pu}-238$ & Liquid/powder & $9.60 \mathrm{E}-10$ & $2.70 \mathrm{E}-03$ & $3.56 \mathrm{E}-07$ \\
\hline $\mathrm{Pu}-239$ & Liquid/powder & $4.56 \mathrm{E}-12$ & $2.50 \mathrm{E}-03$ & $1.82 \mathrm{E}-09$ \\
\hline Ra-226 & Liquid/powder & $2.76 \mathrm{E}-10$ & $5.50 \mathrm{E}-03$ & $5.02 \mathrm{E}-08$ \\
\hline Ru-106 & Liquid/powder & $7.57 \mathrm{E}-10$ & $5.90 \mathrm{E}-01$ & $1.28 \mathrm{E}-09$ \\
\hline $\mathrm{Sb}-125$ & Liquid/powder & $1.04 \mathrm{E}-09$ & $1.40 \mathrm{E}-01$ & $7.43 \mathrm{E}-09$ \\
\hline Sr-90 & Liquid/powder & $1.48 \mathrm{E}-09$ & $5.20 \mathrm{E}-01$ & 2.84E-09 \\
\hline Tc-99 & Liquid/powder & $1.70 \mathrm{E}-06$ & $9.00 \mathrm{E}+00$ & $1.89 \mathrm{E}-07$ \\
\hline Th-228 & Liquid/powder & $2.84 \mathrm{E}-10$ & $2.90 \mathrm{E}-03$ & $9.79 \mathrm{E}-08$ \\
\hline Th-230 & Liquid/powder & $2.11 \mathrm{E}-13$ & $3.20 \mathrm{E}-03$ & $6.59 \mathrm{E}-11$ \\
\hline Th-232 & Liquid/powder & $2.77 \mathrm{E}-10$ & $6.00 \mathrm{E}-04$ & 4.62E-07 \\
\hline U-233 & Liquid/powder & $2.40 \mathrm{E}-08$ & $7.60 \mathrm{E}-03$ & $3.16 \mathrm{E}-06$ \\
\hline $\mathrm{U}-234$ & Liquid/powder & $1.03 \mathrm{E}-06$ & $7.60 \mathrm{E}-03$ & $1.36 \mathrm{E}-04$ \\
\hline U-235 & Liquid/powder & $4.62 \mathrm{E}-08$ & $7.00 \mathrm{E}-03$ & $6.60 \mathrm{E}-06$ \\
\hline U-236 & Liquid/powder & $2.20 \mathrm{E}-10$ & $8.40 \mathrm{E}-03$ & $2.62 \mathrm{E}-08$ \\
\hline U-238 & Liquid/powder & $3.59 \mathrm{E}-06$ & $8.60 \mathrm{E}-03$ & 4.17E-04 \\
\hline U natural & Liquid/powder & 4.73E-05 & 8.00E-03 & $5.92 \mathrm{E}-03$ \\
\hline Xe-133 & Gas & $4.85 \mathrm{E}-01$ & $5.20 \mathrm{E}+01$ & $9.32 \mathrm{E}-03$ \\
\hline $\mathrm{Xe}-135$ & Gas & $5.20 \mathrm{E}-08$ & $7.60 \mathrm{E}+00$ & $6.84 \mathrm{E}-09$ \\
\hline \multirow[t]{2}{*}{$\mathrm{AGC}^{3}$} & Liquid/powder & & & $6.87 \mathrm{E}-04$ \\
\hline & & & TOTAL & $1.67 \mathrm{E}-02$ \\
\hline
\end{tabular}

a J. Leitch, Region 10 EPA, letter dated July 5, 1996, in response to John E. Medema letter, "40 CFR 61 Subpart H Compliance for the Idaho National Laboratory Research Center (IRC),” OPE-EP-96-181, dated June 11, 1996 to Ms. Ann Frankel. 


\section{CFR 61.94(b)}

"In addition to paragraph (a), the annual report will include the following information:"

40 CFR 61.94(b)(1)

"The name and location of the facility."

Idaho National Laboratory (INL) Research Center (IRC) facilities are located on a partially developed 14.3-ha (35.5-acre) plot on the north side of the City of Idaho Falls. Though programs and operations at the IRC are affiliated with INL, the IRC is located within the city limits of Idaho Falls and is not contiguous with INL Site, the nearest boundary of which is approximately $22 \mathrm{mi}$ west of Idaho Falls.

Facilities at the IRC include office, laboratory, and technical support buildings. The largest is a three-story office building connected by an enclosed walkway to a one-story laboratory building containing 66 laboratories. Other buildings at the IRC include the Research Office Building, Physics Building, Electric Vehicle Building, and Systems Analysis Facility.

\section{CFR 61.94(b)(2)}

"A list of the radioactive materials used at the facility."

See Table A-1.

\section{CFR 61.94(b)(3)}

"A description of the handling and processing that the radioactive materials undergo at the facility.”

The IRC is principally an experimental research facility dedicated to a wide range of research areas, including microbiology; geochemistry; materials characterization; welding; ceramics; thermal fluids behavior; materials testing; nondestructive evaluation of materials using standard industrial x-ray processes, $\mathrm{x}$-ray diffraction, and x-ray fluorescence; analytical and environmental chemistry; and biotechnology.

\section{CFR 61.94(b)(4)}

"A list of the stacks or vents or other points where radioactive materials are released to the atmosphere."

Radiological emissions from the IRC could arise from uncontrolled laboratory fume hoods within the facility. Exhaust from most of the fume hoods is released directly to the outside atmosphere via the heat recovery fan system of the IRC heating, ventilating, and air conditioning system. The heat recovery fan system exhausts to the outside via vents on the north side of the mechanical penthouse on top of the IRC laboratory building. Stack height of these vents is $7.6 \mathrm{~m}(25 \mathrm{ft})$. The exhausts from other fume hoods (not exhausted to the heat recovery fan) are released to the atmosphere via a $2.1-\mathrm{m}(7.0-\mathrm{ft})$ stack above the roof or two 8.5-m (28-ft) stacks above the roof.

Emissions can occur from other areas as well. Not all radiological emissions will occur from work in a fume hood. Some work is done on work benches or in bay areas. Work with radionuclides could be done anywhere at the IRC. The likely places include Building 603, System Analysis Facility, and INL Engineering Demonstration Facility. 


\section{CFR 61.94(b)(5)}

"A description of the effluent controls that are used on each stack, vent, or other release point and an estimate of the efficiency of each control device."

No effluent control equipment is associated with any of the IRC's release points.

\section{CFR 61.94(b)(6)}

"Distances from the points of release to the nearest residence, school, business or office and the nearest farms producing vegetables, milk, and meat."

The nearest business is $0.1 \mathrm{~km}(0.0620 \mathrm{mi})$ north of the IRC.

Consistent with 40 CFR 61, Appendix E, no residence is within $10 \mathrm{~m}$ of the IRC, and no vegetables, milk, or meat are produced within $100 \mathrm{~m}$ of the IRC.

\section{CFR 61.94(b)(7)}

"The values used for all other user supplied input parameters for the computer models (e.g., meteorological data) and the source of these data."

Not applicable. 40 CFR 61 Appendix E used for compliance.

\section{CFR 61.94(b)(8)}

"A brief description of all construction and modifications that were completed in the calendar year for which the report is prepared, but for which the requirement to apply for approval to construct or modify was waived under $\$ 61.96$ and associated documentation developed by DOE to support the waiver."

None. 


\section{Appendix B}

Naval Reactors Facility National Emission Standards for Hazardous Air Pollutants-Radionuclides Annual Report for 2010 
B-2 
Naval Reactors Facility

National Emission Standards for Hazardous Air Pollutants

Report on 2010 Radionuclide Emissions 


\section{U. S. Department of Energy \\ Radionuclide Air Emissions Annual Report \\ (under Subpart H of 40 CFR Part 61) \\ Calendar Year 2010}

Site Name: Idaho National Laboratory (INL)

Area: Naval Reactors Facility (NRF)

\section{Area Information for NRF}

Operator: Bechtel Marine Propulsion Corporation

Address: $\quad$ P. O. Box 2068

Idaho Falls, Idaho 83403-2068

Contact: $\quad$ M. A. DiBattista, Manager, Naval Reactors Facility

Phone: (208) 533-5526

Owner: $\quad$ Naval Reactors Idaho Branch Office

Address: $\quad$ P. O. Box 2469

Idaho Falls, Idaho 83403-2469

Contact: $\quad$ C. B. Haynes, Manager, Naval Reactors Idaho Branch Office

Phone: $\quad$ (208) 533-5317 


\section{FACILITY INFORMATION}

\section{Site Description}

The developed area of the Naval Reactors Facility (NRF) covers 84 acres and is located in the westcentral part of the Idaho National Laboratory (INL) site (Figure 1). NRF is located approximately 6.7 miles (10.8 kilometers) from the nearest INL border. The nearest residence is 8.5 miles (13.7 kilometers) north-northwest of NRF. The nearest population center is Howe which is located approximately 10.1 miles (16.2 kilometers) north-northwest of NRF. Section III provides specific information concerning the distances to locations used for dose modeling.

The climate of the INL is characterized as semi-arid. The INL is located on the Snake River Plain with an elevation of approximately 5000 feet (1500 meters). Air masses entering the Snake River Plain from the west lose most of their moisture to precipitation prior to reaching the INL; therefore, annual precipitation at the INL is light. Winds are channeled over the Snake River Plain by bordering mountain ranges so that wind from the southwest predominates over the INL. The second most frequent winds are from the northeast. The meteorological data for the area is used in the dose modeling, as described in Section III.

Established in 1949, NRF is operated for the U. S. Naval Nuclear Propulsion Program by Bechtel Marine Propulsion Corporation, Bettis Atomic Power Laboratory. The principal facilities at NRF are three former naval reactor prototypes (S1W, A1W, and S5G) and the Expended Core Facility (ECF). The S1W, A1W, and S5G prototypes were shut down in October 1989, January 1994, and May 1995, respectively.

Developmental nuclear fuel material samples, naval spent fuel, and irradiated reactor plant components/materials are examined at ECF. The knowledge gained from these examinations is used to improve current designs and to monitor the performance of existing reactors. The naval spent fuel examined at ECF is critical to the design of longer-lived cores, which results in the creation of less spent fuel requiring disposition. NRF also prepares and packages spent naval fuel for dry storage and eventual transportation to a permanent repository. 


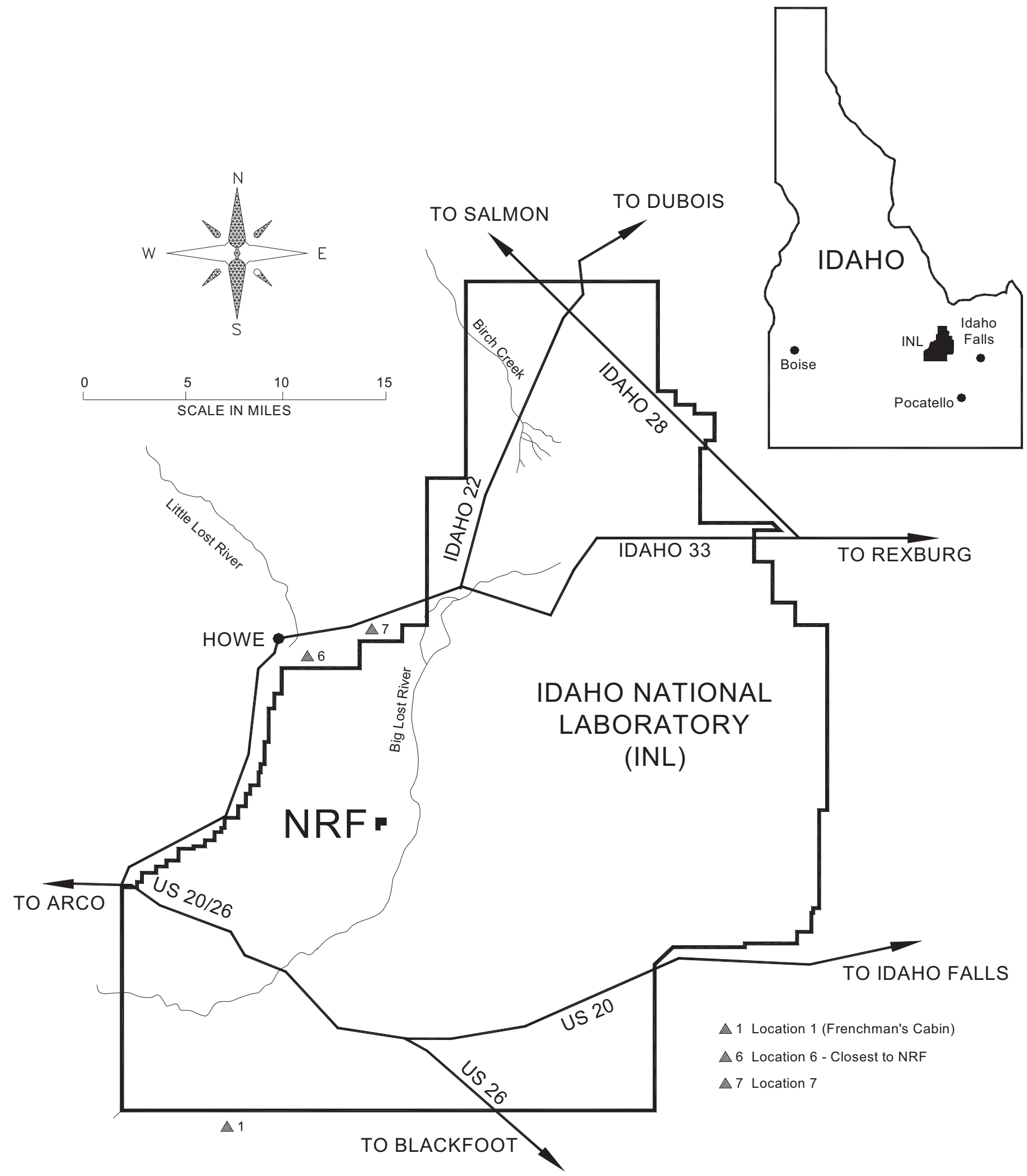

Figure 1. Relation of NRF to the INL. 


\section{Source Descriptions}

NRF receives spent fuel and radioactive components from the U. S. Naval Nuclear Propulsion Program, shipped in Department of Energy (DOE)/Nuclear Regulatory Commission approved shipping containers in accordance with Department of Transportation requirements. The shipments are processed and examined at ECF.

Radioactive materials at NRF include enriched uranium fuel with associated fission products, activation products, and activated corrosion and wear products. Various radiation sources are used for calibrating and checking equipment, verifying shielding, and performing radiography. Soil with low levels of radioactivity from past releases is also present at NRF.

Radioactive materials are handled and processed in several areas at NRF, including shielded hot cells, chemical and metallurgical laboratories, water pools, and radioactive material storage areas. Physical, chemical, and metallurgical testing of small quantities of highly radioactive material specimens is performed in the ECF shielded hot cells. Radioactive work conducted within the ECF highbay water pools consists of unloading radioactive specimens from shipping containers, fuel examinations, removal of non-fuel structural pieces, and storage of fuel. Segregation and repackaging of radioactive waste are performed within the S5G highbay, and decontamination of inactive radiological systems proceeds throughout NRF controlled areas. Radioactive work is performed in appropriate containment. Storage and movement of radioactive materials are under strict control. Special laboratory facilities are available for the chemical analysis of low-level radioactive samples.

All radioactive material is controlled by a radioactive material accountability system and maintained in designated storage areas. All movements of radioactive material within the facility are performed under escort of qualified radiological controls personnel and tracked in the accountability system.

Radioactive liquids are used to support operations. Radioactive liquids may be processed through a series of filters and demineralizers for reuse.

Disposable materials and waste products associated with the handling of radioactive materials are controlled and tracked as radioactive waste. The waste is temporarily stored on-site in designated storage areas until sufficient quantities accumulate to comprise a shipment to a DOE low-level disposal site. 
Radionuclide emissions to the atmosphere can come from three main sources at NRF:

(1) ECF, where spent fuel from naval cores and contaminated materials such as anti-contamination clothing, tools, and other equipment are handled. Radioactive water is present in the water pools where the fuel is located. Spent fuel is unloaded from shipping containers and is packaged for long term storage at a permanent repository.

(2) S1W, A1W, and S5G Prototype Reactors. Although the reactors have been shut down and defueled, routine inspections of the reactor compartments are conducted and the air exhausted from these facilities is monitored. At the S5G prototype, contaminated materials such as tools, equipment, anti-contamination clothing, and contaminated waste are handled. Analyses are performed on radioactive materials in chemistry laboratories in the A1W prototype building.

(3) Fugitive Soil Emissions, from areas surrounding NRF which potentially contain low levels of radioactivity in the soil that are exposed to the wind.

\section{AIR EMISSIONS DATA}

NRF has a number of stacks and vents with the potential to emit low quantities of radionuclides. These emissions are monitored and calculated by NRF. The data are included in the calculation of the INL's annual effective dose equivalent (EDE) to members of the public.

Continuous monitoring is required by 61.93(b) of 40 CFR 61, Subpart H, for emission points that have a potential to emit radionuclides in quantities that could result in an EDE to a member of the public in excess of 1 percent of the 10 millirem $\left(1 \times 10^{-4}\right.$ sievert $)$ per year standard, which is 0.1 millirem $(1 \mathrm{x}$ $10^{-6}$ sievert) per year. None of the emission points at NRF qualify for the continuous monitoring requirement; all emission points are below the 0.1 millirem $\left(1 \times 10^{-6}\right.$ sievert $)$ per year criteria. For emission points whose potential to emit is below this criteria, periodic confirmatory measurements are required to verify the low emissions.

Table II-1 identifies potential point sources of radionuclide air emissions. The table contains identification codes for area, building, and vent; a general description; a description of the effluent controls and their efficiencies, if applicable; and those emission sources that were monitored.

Table II-2 identifies potential fugitive sources of radionuclide air emissions. The only fugitive source is windblown soil from areas on NRF property surrounding the developed facility, which contain low levels of radioactivity from past releases. Fugitive sources have no effluent control or monitoring.

Tables II-3 and II-4 list the combined radionuclide emissions from the point sources and fugitive sources. The tables include measured values for those radionuclides that are routinely monitored and calculated values for those radionuclides that are not monitored. For determining the EDE, the gross alpha radioactivity is conservatively modeled as plutonium-239 and the gross beta radioactivity is conservatively modeled as strontium-90. 
Table II-1. Potential Radiological Air Emission Point Sources at NRF During 2010

\begin{tabular}{|c|c|c|c|c|}
\hline \multicolumn{5}{|c|}{ Nearest Residence, School, Business or Farm: 13.7 kilometers NNW } \\
\hline $\begin{array}{l}\text { AREA } \\
\text {-BLDG } \\
\text {-VENT No. }\end{array}$ & SOURCE DESCRIPTION & $\begin{array}{c}\text { EFFLUENT } \\
\text { CONTROL } \\
\text { DESCRIPTION }\end{array}$ & $\begin{array}{l}\text { EFFICI- } \\
\text { ENCY }^{1}\end{array}$ & $\begin{array}{l}\text { MONI- } \\
\text { TORED }^{2}\end{array}$ \\
\hline NRF-601-023 & S1W Reactor Compartment & None ${ }^{3}$ & NA & No \\
\hline NRF-601-HBRV & S1W High Bay Ventilation & None $^{3}$ & NA & Yes \\
\hline NRF-616-012, 021 & $\begin{array}{c}\text { A1W Operations Building and Site } \\
\text { Chemistry }\end{array}$ & None $^{3}$ & NA & Yes \\
\hline NRF-616-PCMA & $\begin{array}{l}\text { A1W Primary Components Maintenance } \\
\text { Area and Extension }\end{array}$ & None $^{3}$ & NA & No \\
\hline NRF-617-013 & A1W Reactor Compartment 3A & HEPA Filter & $99.95 \%$ & Yes \\
\hline NRF-617-020 & A1W Reactor Compartment 3B & HEPA Filter & $99.95 \%$ & Yes \\
\hline NRF-618-099 & ECF Stack Number 1 & $\begin{array}{l}\text { HEPA Filter } \\
\text { Carbon Filter }\end{array}$ & $\begin{array}{c}99.95 \% \\
90-99.9 \%\end{array}$ & Yes + \\
\hline NRF-618-103 & ECF Stack Number 2 & HEPA Filter & $99.95 \%$ & Yes+ \\
\hline NRF-618-237 & ECF Stack Number 3 & HEPA Filter & $99.95 \%$ & Yes + \\
\hline NRF-618-HBRV & ECF High Bay Roof Vents & None ${ }^{3}$ & NA & Yes \\
\hline NRF-633A-057 & $\begin{array}{l}\text { S5G Radioactive Area Ventilation } \\
\text { (RAV) System }\end{array}$ & HEPA Filter & $99.95 \%$ & Yes \\
\hline NRF-633A-HBRV & S5G High Bay Roof Vents & None $^{3}$ & NA & Yes \\
\hline NRF-628A-MSC & Bldg 628A Temporary Ventilation ${ }^{4}$ & HEPA Filter & $99.95 \%$ & Yes \\
\hline
\end{tabular}

1. HEPA filters are tested by the manufacturer prior to delivery to NRF and by NRF during the life of the filter. The manufacturer tests the efficiency for 0.3 -micron monodispersed dioctylphthalate (DOP) particles to a minimum of 99.97 percent. NRF tests the efficiency for 0.7 -micron polydispersed DOP particles to a minimum of 99.95 percent. The carbon filters have an efficiency of 99.9 percent for the removal of radioactive iodine when new. Their efficiency lessens with use, as the carbon adsorbent depletes. The carbon filters are replaced when efficiency drops to 90 percent.

2. "No" indicates that the source was not monitored during 2010 because it did not operate during 2010. "Yes" indicates that the source was monitored, and the measured emissions are included in this report. "Yes+" indicates that the source was monitored, and both measured and calculated emissions are included in this report. (Because some gaseous radionuclides could not be measured, the amounts of these radionuclides were calculated based on the amount of process production.)

3. Subsystems that exhaust within the areas ventilated by these sources may have HEPA filters.

4. This is a temporary exhaust system set up in December 2010 to provide ventilation for remediation work in the Radioactive Waste Disposal Equipment Building. 
Table II-2. Potential Radiological Air Emission Fugitive Sources at NRF During 2010

\begin{tabular}{|ccccc|}
\hline \multicolumn{5}{|c|}{ Nearest Residence, School, Business or Farm: 13.7 kilometers NNW } \\
\hline AREA- & & EFFLUENT & EFFI- & MONI- \\
LOCATN- & SOURCE DESCRIPTION & CONTROL & CIENCY & TORED \\
I.D. CODE & Fugitive Soil & DESCRIPTION & & \\
\hline \hline NA & None & NA & No \\
\hline
\end{tabular}

Table II-3. Point Source Releases From NRF During 2010

\begin{tabular}{|lccc|}
\hline Radionuclide & Symbol & $\begin{array}{c}\text { Release } \\
\text { (curies) }\end{array}$ & $\begin{array}{c}\text { Release } \\
\text { (becquerels)* }\end{array}$ \\
\hline Carbon-14 & $\mathrm{C}-14$ & $1.0 \mathrm{E}+00$ & $3.7 \mathrm{E}+10$ \\
\hline Gross alpha (modeled as plutonium-239) & Pu-239 & $1.7 \mathrm{E}-06$ & $6.3 \mathrm{E}+04$ \\
\hline Gross beta (modeled as strontium-90) & Sr-90 & $5.6 \mathrm{E}-05$ & $2.1 \mathrm{E}+06$ \\
\hline Tritium & $\mathrm{H}-3$ & $2.1 \mathrm{E}-02$ & $7.8 \mathrm{E}+08$ \\
\hline Iodine-131 & $\mathrm{I}-131$ & $4.1 \mathrm{E}-06$ & $1.5 \mathrm{E}+05$ \\
\hline Iodine-129 & $\mathrm{I}-129$ & $2.9 \mathrm{E}-05$ & $1.1 \mathrm{E}+06$ \\
\hline Krypton-85 & $\mathrm{Kr}-85$ & $2.5 \mathrm{E}-01$ & $9.3 \mathrm{E}+09$ \\
\hline Total & & $1.3 \mathrm{E}+00$ & $4.8 \mathrm{E}+10$ \\
\hline
\end{tabular}

* One curie equals $3.7 \mathrm{E}+10$ becquerels.

Table II-4. Fugitive Source Releases From NRF During 2010

\begin{tabular}{|lccc|}
\hline Radionuclide & Symbol & $\begin{array}{l}\text { Release } \\
\text { (curies) }\end{array}$ & $\begin{array}{c}\text { Release } \\
\text { (becquerels)* }\end{array}$ \\
\hline \hline Cobalt-60 & Co-60 & $6.8 \mathrm{E}-06$ & $2.5 \mathrm{E}+05$ \\
\hline Cesium-137 & Cs-137 & $9.0 \mathrm{E}-05$ & $3.3 \mathrm{E}+06$ \\
\hline Total & & $9.7 \mathrm{E}-05$ & $3.6 \mathrm{E}+06$ \\
\hline
\end{tabular}

* One curie equals $3.7 \mathrm{E}+10$ becquerels. 


\section{DOSE ASSESSMENTS \\ Summary}

Table III-1 summarizes the EDE results for point sources, fugitive sources, and both combined. The total EDE from all NRF sources was determined to be $3.0 \times 10^{-4}$ millirem $\left(3.0 \times 10^{-9}\right.$ sievert $)$ and occurred at a location 8.5 miles (13.7 kilometers) north-northwest of NRF. The NRF EDE is for information only; it is the EDE from all INL sources combined that is used to show compliance with the 40 CFR 61.92 standard.

Table III-1. Effective Dose Equivalents from Sources at NRF During 2010

\begin{tabular}{|ccc|}
\hline Release Point & $\begin{array}{c}\mathrm{EDE}^{1} \\
(\mathrm{mrem})\end{array}$ & $\begin{array}{c}\mathrm{EDE}^{1} \\
(\mathrm{~Sv})^{2}\end{array}$ \\
\hline \hline 1. Point Sources & $3.0 \mathrm{E}-04$ & $3.0 \mathrm{E}-09$ \\
\hline 2. Fugitive Sources & $3.2 \mathrm{E}-06$ & $3.2 \mathrm{E}-11$ \\
\hline \hline Total: & $3.0 \mathrm{E}-04$ & $3.0 \mathrm{E}-09$ \\
\hline
\end{tabular}

1. The EDE shown is for the NRF maximally exposed individual (Figure 1, Location 6).

2. One millirem equals 1.0E-05 sievert (Sv).

\section{Description of Dose Model and Summary of Input Parameters}

\section{General}

The CAP-88 computer code (PC Version 3) was used to calculate the EDE from the NRF releases. CAP-88 is approved for use by the Environmental Protection Agency (EPA) for demonstrating compliance with 40 CFR 61 Subpart H, "National Emission Standards for Emissions of Radionuclides Other Than Radon From Department of Energy Facilities." The output from CAP-88 is the EDE, which includes the 50-year committed EDE (CEDE) from internal exposure through the ingestion and inhalation pathways and the external EDE from ground deposition and air immersion.

Site-specific 2010 wind data was used, supplied by the National Oceanic and Atmospheric Administration (NOAA). Emissions from all NRF sources were modeled as ground-level releases with no plume rise, as the most conservative approach. All sources were modeled as originating from the center of the facility. Other user-supplied input parameters are as follows:

Wind Data File: NRFL10.WND per NOAA

Annual Average Temperature: $6.2 \mathrm{deg} \mathrm{C}$ average in 2010 per NOAA

Annual Rainfall: $24.9 \mathrm{~cm}$ in 2010 per NOAA

Humidity: $4 \mathrm{~g} / \mathrm{m}^{3}$ long term INL average calculated from NOAA data

Lid Height: $800 \mathrm{~m}$ per NOAA

Agricultural Class: Rural

The dose from daughter progeny is included by the CAP-88 program. Some radionuclides such as cesium-137 and strontium-90 have daughter progeny that emit radioactivity which is as significant as the parent's radioactivity. 


\section{Compliance Assessment}

\section{Maximally Exposed Individual}

Subpart H of 40 CFR 61 requires that emissions of radionuclides to the ambient air from DOE facilities shall not exceed those amounts which would cause any member of the public to receive an EDE of 10 millirem ( $1 \times 10^{-4}$ sievert $)$ per year. "Member of the public" is any offsite point where there is a residence, school, business, or office.

Two locations near the INL boundary were evaluated to determine which received the highest dose from NRF emissions. The first is the nearest "residence, school, business, or office" to NRF. It is a residence 8.5 miles (13.7 kilometers) to the north-northwest (Figure 1, Location 6). The second location is another residence located 9.8 miles (15.8 kilometers) north of NRF (Figure 1, Location 7). Although Location 7 is a greater distance from NRF, wind direction in some years can cause it to receive a higher dose from NRF emissions than Location 6 . The dose at both of these locations was evaluated using the CAP- 88 program, and Location 6 was found to have the higher dose from 2010 emissions.

The EDE at Location 6 from NRF emissions is given for information only. For compliance purposes, the EDE from all INL emissions combined must comply with the 40 CFR 61.92 standard of 10 millirem per year. NRF emissions are combined with emissions from other INL facilities to determine the overall EDE for the INL.

\section{ADDITIONAL INFORMATION}

The EPA requires in 40 CFR 61 Subpart $\mathrm{H}$ that a "brief description of all construction and modifications which were completed in the calendar year for which the report is prepared, but for which the requirement to apply for approval to construct or modify was waived" be included.

There were no construction projects or modifications completed at NRF during 2010 which fall under this requirement.

\section{SUPPLEMENTAL INFORMATION}

The following information is provided at the request of DOE Headquarters and is not required as part of the annual National Emission Standards for Hazardous Air Pollutants reporting requirements (under 40 CFR Section 61.94).

\section{REQUEST: Provide an estimate of the collective effective dose equivalent (person-rem per year) for 2010 releases.}

An estimate of the collective effective dose equivalent (person-rem per year) will be provided in the Idaho National Laboratory Site Environmental Report for Calendar Year 2010. 
REQUEST: Provide information on the status of compliance with Subparts Q and T of 40 CFR Part 61 if pertinent.

Subpart Q of 40 CFR Part 61, "National Emission Standards for Radon Emissions From Department of Energy Facilities," is applicable to the design and operation of storage and disposal facilities for radium-containing material that emit radon-222 into the air. Subpart Q is not applicable to the Naval Reactors Facility. Subpart T of 40 CFR Part 61, "National Emission Standards for Radon Emissions From the Disposal of Uranium Mill Tailings," is not applicable to the Naval Reactors Facility.

REQUEST: Provide information on radon-220 emissions from sources containing uranium-232 and thorium-232 where emissions potentially can exceed 0.1 millirem $\left(1 \times 10^{-6}\right.$ sievert $)$ per year to the public or 10 percent of the non-radon dose to the public.

The Naval Reactors Facility does not have any sources of uranium-232 or thorium-232 emissions that potentially can exceed 0.1 millirem $\left(1 \times 10^{-6}\right.$ sievert $)$ per year to the public or 10 percent of the nonradon dose to the public.

REQUEST: Provide information on non-disposal and non-storage sources of radon-222 emissions where emissions potentially can exceed 0.1 millirem $\left(1 \times 10^{-6}\right.$ sievert $)$ per year to the public or 10 percent of the non-radon dose to the public.

The Naval Reactors Facility does not have any non-disposal or non-storage sources of Radon-222 emissions that potentially can exceed 0.1 millirem $\left(1 \times 10^{-6}\right.$ sievert $)$ per year to the public or 10 percent of the non-radon dose to the public.

REQUEST: For the purpose of assessing facility compliance with the National Emission Standards for Hazardous Air Pollutants effluent monitoring requirements of Subpart H under Section 61.93(b), give the number of emission points subject to the continuous monitoring requirements, the number of these emission points that do not comply with the Section 61.93(b) requirements, and if possible, the cost for upgrades. Describe site periodic confirmatory measurement plans. Indicate the status of the quality assurance program described by Appendix B, Method 114.

The Naval Reactors Facility does not have any emission points that require continuous monitoring under Section 61.93(b). However, confirmatory measurements were accomplished by calculating the maximum unabated emissions for radiological emission points at NRF to determine if continuous monitoring is required under Section 61.93. Periodic confirmatory measurements were also accomplished by use of calculations and samples to determine the actual emissions in 2010.

Although no NRF emission points require continuous monitoring, a quality assurance (QA) program is incorporated into the environmental monitoring program. The QA program includes equipment calibration, the use of blanks and known standards, and the annual review and validation of radioactive airborne emission data by peer reviewers. 